\title{
Denitrification and nutrient assimilation on a restored oyster reef
}

\author{
M. Lisa Kellogg ${ }^{1, *}$, Jeffrey C. Cornwell ${ }^{2}$, Michael S. Owens ${ }^{2}$, Kennedy T. Paynter ${ }^{3,4}$ \\ ${ }^{1}$ Virginia Institute of Marine Science, College of William \& Mary, Gloucester Point, Virginia 23062, USA \\ ${ }^{2}$ University of Maryland Center for Environmental Science, Horn Point Laboratory, Cambridge, Maryland 21613, USA \\ ${ }^{3}$ Chesapeake Biological Laboratory, University of Maryland Center for Environmental Science, Solomons, Maryland 20688, USA \\ ${ }^{4}$ Department of Biology, University of Maryland, College Park, Maryland 20742, USA
}

ABSTRACT: At a restored reef site and a control site in the Choptank River, Maryland, USA, we partially quantified the effect of oyster reef restoration on the removal of nutrients from the water column by determining seasonal fluxes of oxygen $\left(\mathrm{O}_{2}\right)$, ammonium $\left(\mathrm{NH}_{4}{ }^{+}\right)$, combined nitrate and nitrite $\left(\mathrm{NO}_{2+3}\right)$, di-nitrogen $\left(\mathrm{N}_{2}\right)$ and soluble reactive phosphorus (SRP) and by assessing the assimilation of nutrients by macrofauna. Fluxes of $\mathrm{O}_{2}, \mathrm{NH}_{4}{ }^{+}$, $\mathrm{NO}_{2+3}$ and SRP at the restored site were enhanced by at least one order of magnitude during all seasons. Seasonal denitrification rates at the restored site, measured as flux of $\mathrm{N}_{2}-\mathrm{N}$, ranged from 0.3 to $1.6 \mathrm{mmol} \mathrm{N}_{2}-\mathrm{N} \mathrm{m}^{-2} \mathrm{~h}^{-1}$, with August rates among the highest ever recorded for an aquatic system. In addition to oysters (131 oysters $\mathrm{m}^{-2}$; average shell height $=114 \mathrm{~mm}$; age $=2$ to $7 \mathrm{yr}$ ), the restored reef provided habitat for 24585 other macrobenthic organisms per square meter compared to 2265 organisms $\mathrm{m}^{-2}$ at the control site. Restoration enhanced the average standing stock of assimilated nutrients by $95 \mathrm{~g} \mathrm{~N} \mathrm{~m}^{-2}$ and $15 \mathrm{~g} \mathrm{P} \mathrm{m}^{-2}$. Nitrogen and phosphorus in shells of live oysters and mussels accounted for 47 and $48 \%$ of total nitrogen and phosphorus standing stocks, respectively. Our results demonstrate that oyster reef restoration can significantly increase denitrification rates and enhance nutrient sequestration via assimilation into bivalve shells.

KEY WORDS: Restoration - Crassostrea virginica • Biogeochemistry · Denitrification · Ecosystem services · Nitrogen · Phosphorus - Water quality

Resale or republication not permitted without written consent of the publisher

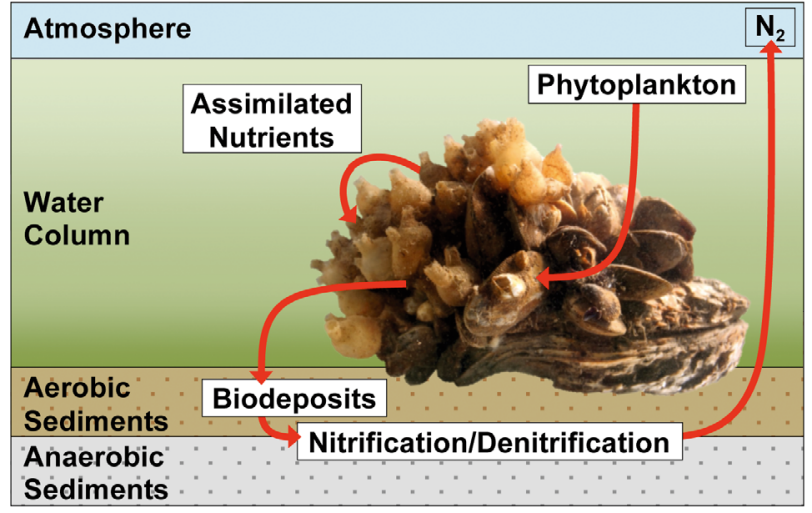

Oyster reefs reduce eutrophication by enhancing denitrification rates and assimilating nutrients into macrofauna.

Image: M. L. Kellogg

\section{INTRODUCTION}

Global loss of $85 \%$ of oyster reef ecosystems over the past $130 \mathrm{yr}$ (Beck et al. 2011) has led to both growing recognition of the services once provided by healthy oyster reef ecosystems (Grabowski et al. 2012) and increasing interest in restoring these ecosystems. In Chesapeake Bay, USA, populations of the native oyster Crassostrea virginica have been reduced to $<1 \%$ of historic levels through a combination of overharvesting, poor management practices and the impacts of 2 oyster diseases (Wilberg et al. 2011 and references therein). Between 1990 and 2007, oyster reef restoration activities were under- 
taken at 594 locations within Chesapeake Bay and the Maryland and Virginia Coastal Bays (Kennedy et al. 2011). Although many restoration efforts focused on increasing substrate available for settlement of oyster larvae, a substantial number also targeted areas where natural larval supply was a limiting factor. These efforts relied on producing oyster larvae in a hatchery, setting them on adult oyster shell and transplanting those juveniles to the restoration site. Since 2002, this has been the primary method used for oyster reef restoration in the Maryland portion of Chesapeake Bay (Kennedy et al. 2011) and is being used with increasing frequency in other parts of the United States (Brumbaugh \& Coen 2009).

The expense of oyster reef restoration, especially when hatchery-produced juvenile oysters are used, raises the question of whether the benefits of oyster reef restoration are worth the investment. Quantifying the benefits of any particular oyster reef restoration effort is complicated because they are diverse, often site-dependent and, in some cases, difficult to measure. Although significant progress has been made in quantifying the benefits of oyster reefs in terms of enhanced (1) filtration and clarity of the water column (Grizzle et al. 2008), (2) abundance and diversity of benthic invertebrates (Rodney \& Paynter 2006), (3) abundance and diversity of mobile crustaceans and fishes (Stunz et al. 2010 and references therein) and (4) fishery production (Peterson et al. 2003), less progress has been made in quantifying the impacts of oyster reefs on nutrient cycling (but see: Newell et al. 2005, Piehler \& Smyth 2011, Smyth et al. 2013).

Two poorly quantified benefits of oyster reef restoration are removal of nitrogen via enhanced denitrification and assimilation of nutrients into the tissues and shells of reef organisms. Oysters, along with other reef-associated filter-feeding organisms, modify biogeochemical cycles by filtering large quantities of organic matter from the water column (Fig. 1), most of which is either used directly for growth and maintenance or is deposited on the sediment surface as feces and/or pseudofeces (i.e. biodeposits). In many subtidal environments, a common setting for oyster reef restoration, these biodeposits concentrate organic material in aerobic environments with low light levels. These conditions are conducive to efficient removal of nitrogen by microbially mediated denitrification (Newell et al. 2002). Oyster reefs also provide habitat for an abundant and diverse reef-associated macrofaunal community. As these organisms grow, they assimilate nitrogen and phosphorus. While a significant portion of these nutrients is rapidly recycled back into the system, nutrients assimilated into bivalve shells represent a means of long-term sequestration. Nitrogen removal is likely further enhanced by the activities of high densities of deposit-feeding and bioturbating organisms (Rodney \& Paynter 2006, Nizzoli et al. 2007). Restoration of oyster reefs adjacent to deep water in eutrophic estuar-

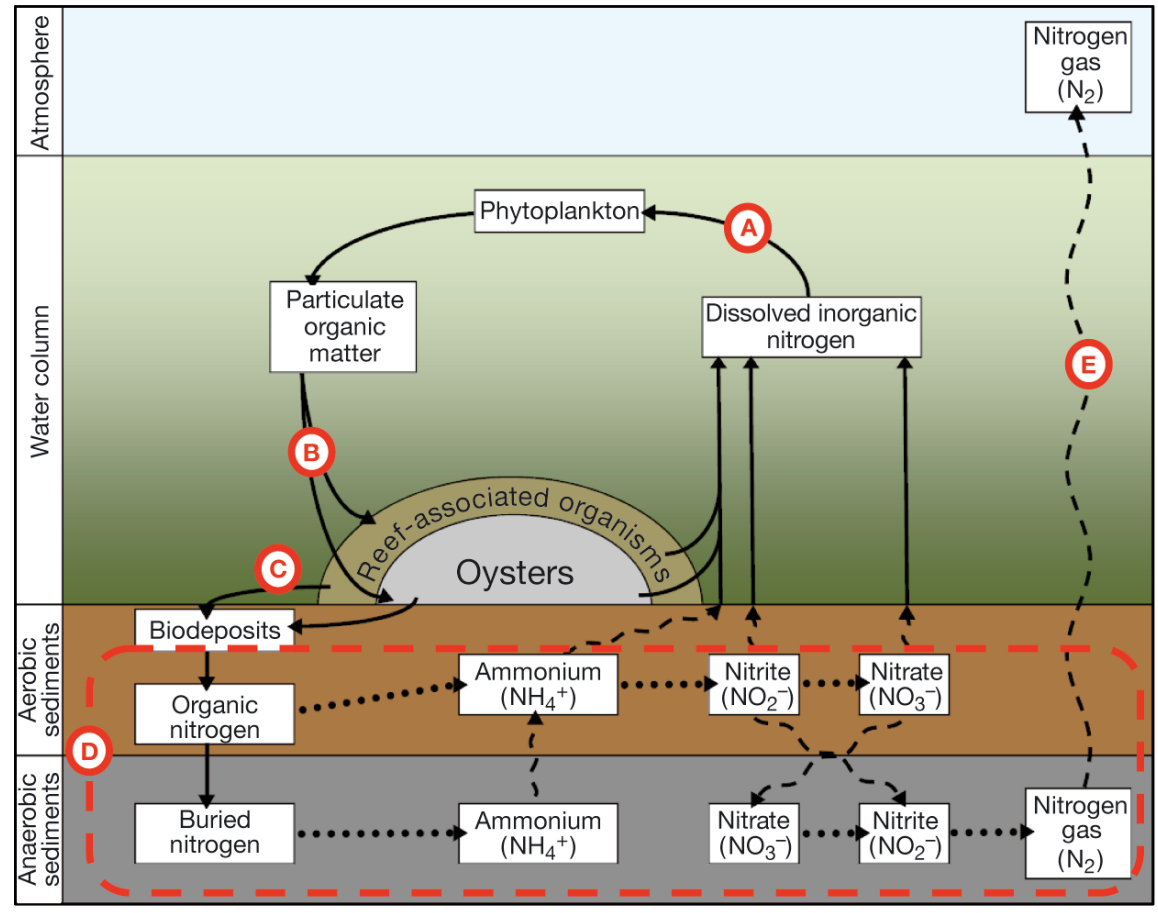

Fig. 1. Primary nitrogen pathways associated with oyster reefs at intermediate depths in Chesapeake Bay, USA: phytoplankton use dissolved inorganic nitrogen for their growth (A), oysters and other reef-associated organisms filter phytoplankton and other particulate organic matter from the water column (B), some of the associated nitrogen is incorporated into organisms and some is deposited on the surface of the sediments (C), and, given the right conditions, a portion of the nitrogen in these biodeposits is transformed into nitrogen gas (D) which diffuses out of the sediments back to the atmosphere (E) where it is no longer available to phytoplankton for growth (diagram adapted from Newell et al. 2005) 
ies similar to Chesapeake Bay has the added benefit of removing phytoplankton and other particulates from the water column before they can be deposited in areas with reduced denitrification and enhanced ammonium regeneration due to hypoxic and/or anoxic conditions in summer (Newell et al. 2005).

Prior studies of the effects of oyster communities on nitrogen cycling have included benthic tunnels in marsh creeks (Dame et al. 1989), core incubations to simulate the effects of oyster biodeposits (Newell et al. 2002, Holyoke 2008) and incubations of sediment cores collected adjacent to oyster clumps (Piehler \& Smyth 2011, Smyth et al. 2013). All of these studies have either measured fluxes in intertidal or shallow subtidal waters in the photic zone and/or have excluded oysters and other reef-associated organisms from their measurements. Extrapolating from these studies to deeper subtidal reefs is problematic because (1) biogeochemical processes are expected to differ between reefs within and below the euphotic zone (Newell et al. 2005), (2) the physical structure of an oyster reef provides numerous microhabitats that likely facilitate nitrification and denitrification and (3) the burrowing and feeding activities of reefassociated organisms likely alter biogeochemical cycles (Nizzoli et al. 2007 and references therein).

Extrapolating existing data to estimate nutrient assimilation by restored oyster reef organisms is also difficult. Prior studies of oyster assimilation have used selected strains and/or grown oysters under environmental conditions that differ from natural or restored oyster reefs (Higgins et al. 2011, Carmichael et al. 2012). Prior studies documenting the macrofaunal community found on restored subtidal oyster reefs (e.g. Rodney \& Paynter 2006) have not measured the nutrient content of each species.

The present study focused on assessing alterations in nutrient dynamics attributable to reef restoration in terms of both the amount of nitrogen removed via denitrification and the amount of nitrogen and phosphorus assimilated into the tissues and shells of oyster reef organisms. While we recognize that biodeposition and subsequent burial of nutrients is also an important nutrient removal pathway (Newell et al. 2005), estimating this loss term was beyond the scope of the present study. We hypothesized that oyster reef restoration in subtidal environments would enhance denitrification rates and increase the standing stock of assimilated nutrients. Using a combination of field sampling and laboratory flux chamber incubations we (1) quantified denitrification rates by comparing fluxes of nitrogen gas in samples collected from a restored oyster reef site (hereafter 'restored site') to those collected from an adjacent site that had not been restored (hereafter 'control site'); (2) assessed seasonal changes in denitrification rates and calculated annual values; and (3) compared the average abundance, biomass and standing stock of nutrients contained in the tissues and shells of organisms at the restored and control sites.

\section{MATERIALS AND METHODS}

\section{Study area}

Our study focused on a restored oyster reef ( $38^{\circ} 34.411^{\prime} \mathrm{N}, 76^{\circ} 3.131^{\prime} \mathrm{W}$ ) in the Choptank River and an adjacent control site $\left(38^{\circ} 34.308^{\prime} \mathrm{N}, 76^{\circ} 3.153^{\prime} \mathrm{W}\right)$ that was suitable for restoration, both located within the Shoal Creek historic oyster bar near Cambridge, Maryland, USA (Fig. 2). Restoration activities in this area included placement of oyster shell in 2003 followed by placement of hatchery-produced juvenile oysters settled on adult oyster shells in 2003, 2006 and 2007 (S. Allen, MD Oyster Recovery Partnership, pers. comm.). Divers identified a 'restored' site (characterized by evidence of restoration activity, i.e. planted shells and oysters) and a 'control' site (characterized by a lack of planted shell and oysters) within this area suitable for our experiments and established a $4 \mathrm{~m} \times 4 \mathrm{~m}$ experimental plot at each site (Fig. 3). Because sites were only $\sim 190 \mathrm{~m}$ apart and both were at $\sim 4 \mathrm{~m}$ depth, physical conditions were expected to be similar.

Both control and restored sites were characterized by firm substratum. At the control site, the substratum surface consisted primarily of sand mixed with fine sediments and shell fragments covering a dense layer of oyster shell, presumably the remains of a past reef. Substratum at the restored site was covered in a layer of exposed oyster shell and clumps of adult oysters from prior restoration efforts. Because oyster density at this site had not yet reached $>100$ adult oysters $\mathrm{m}^{-2}$, a target density commonly used for oyster reef restoration projects in the Chesapeake Bay, divers collected oyster clumps from the surrounding area and placed them within the experimental plot to increase oyster abundance. All manipulations were completed $>12 \mathrm{wk}$ prior to the start of experiments to allow time for the system to equilibrate. Prior to the initial deployment of sampling trays (described below), each $4 \mathrm{~m} \times 4 \mathrm{~m}$ experimental plot was subdivided into 4 equal subplots. Within each subplot, 5 potential deployment sites were identified and the sampling sequence was randomly 


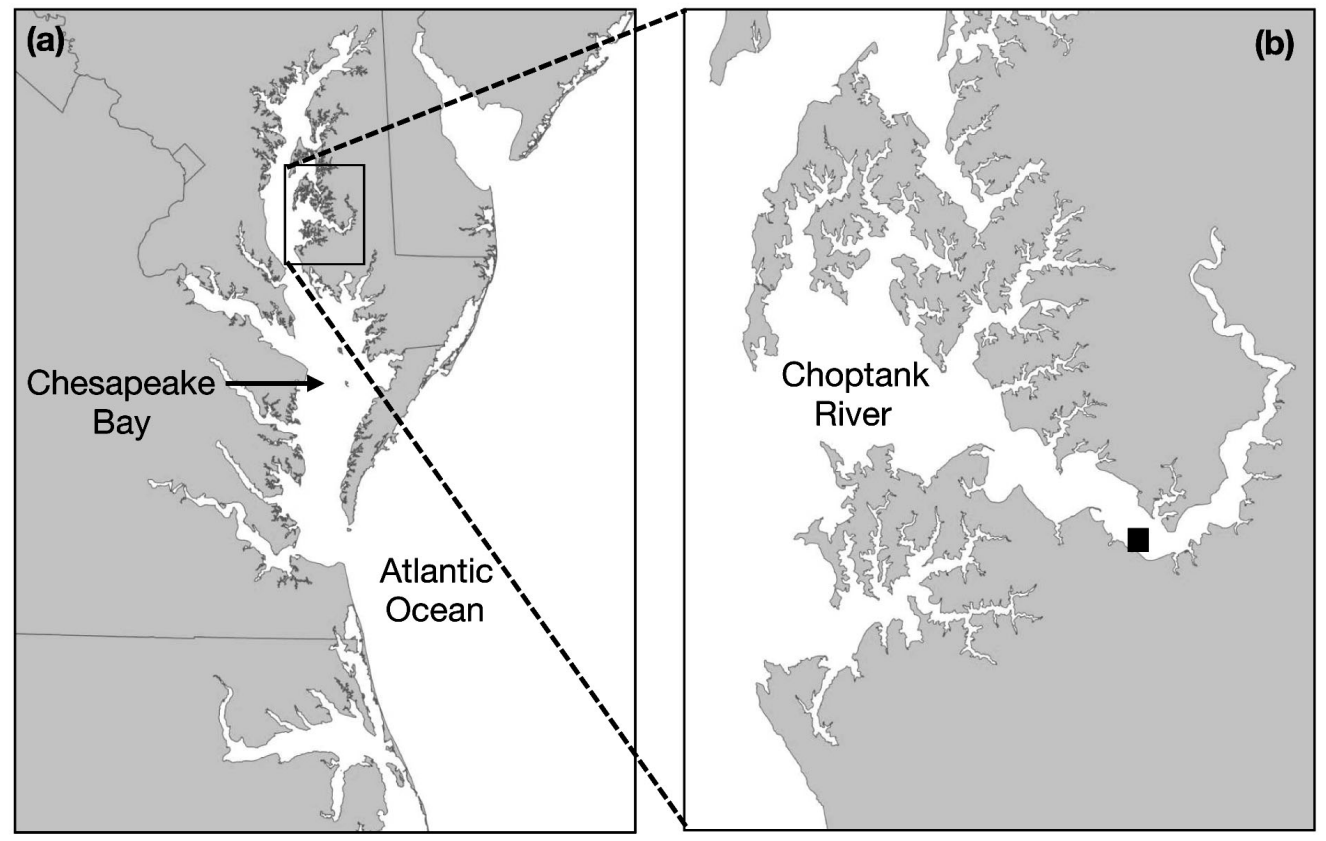

Fig. 2. Map of study area showing (a) the location of Choptank River within Chesapeake Bay and (b) the location of our study sites (ם) within the Choptank River. The control site was $\sim 190 \mathrm{~m}$ away from the restored site and both fell within the single location indicated on the map

assigned (Fig. 3). One sampling site was used for pilot studies and 4 were used for seasonal sampling.

To characterize environmental conditions, a YSI 6600 was placed at each site to record temperature, sal-

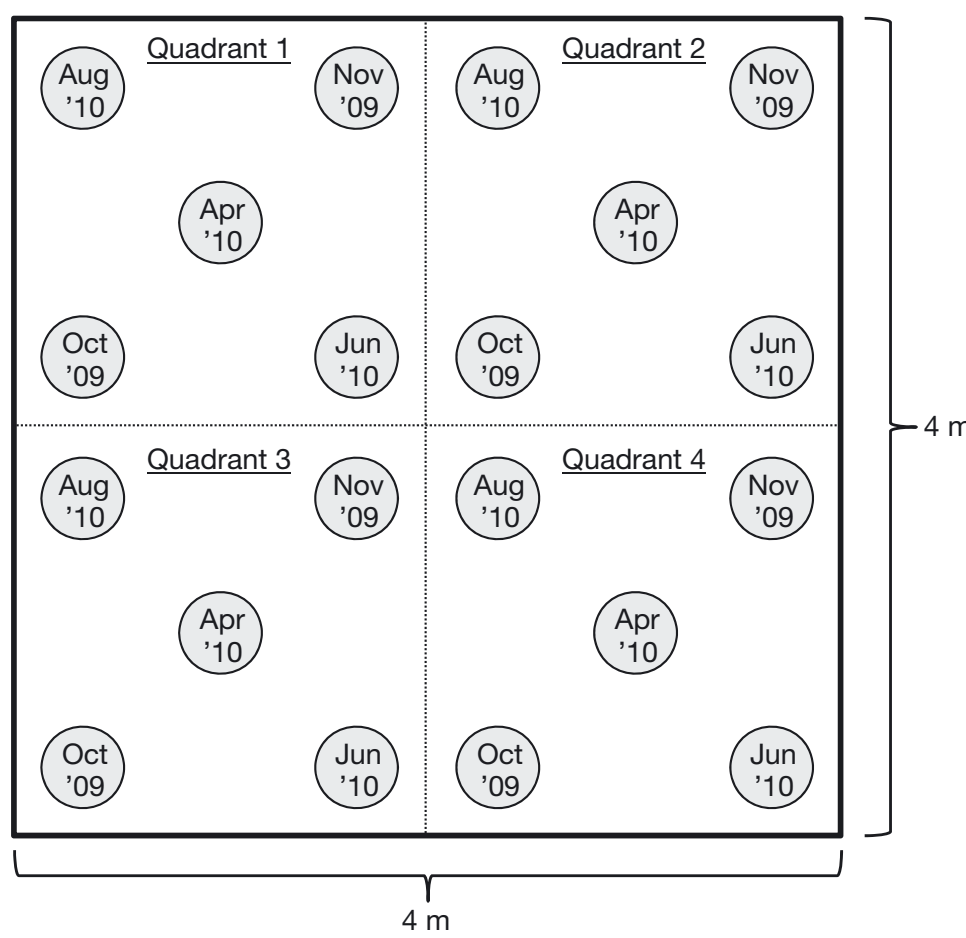

Fig. 3. Diagram of an experimental plot; one plot was located at the restored site, and one at the control site. Each circle designates a sampling location (drawn to scale) and is labeled with the date it was sampled. October samples were collected as part of pilot studies to determine the details of incubation methods. As indicated in the diagram, 4 samples were collected from each site during each sampling period inity and dissolved oxygen every 5 min during each seasonal deployment. We determined the total volume of sediments in sampling trays during each sampling period by measuring the height of the sediments in the tray at 8 locations and multiplying the average height by the area of the tray. To characterize the surface sediments at each site, we collected samples from the top $1 \mathrm{~cm}$ of each sampling tray at the end of the August sampling period. Distribution of fine-grained sediment size classes was determined after samples were wet sieved at $64 \mu \mathrm{m}$ to separate mud from larger sediment particles (Coakley \& Syvitski 1991). Total organic content in sediments was determined by combustion at $450^{\circ} \mathrm{C}$ for $4 \mathrm{~h}$. After removing large pieces of shell, sediments were dried $\left(65^{\circ} \mathrm{C}\right)$ and ground and total sediment carbon and nitrogen concentrations were determined using a CHN analyzer. Carbonate carbon was analyzed by gas chromatography after acidification (Stainton 1973), and organic carbon was estimated as the difference between total carbon and carbonate carbon.

\section{Biogeochemical flux measurement}

Fluxes of oxygen $\left(\mathrm{O}_{2}\right)$, ammonium $\left(\mathrm{NH}_{4}{ }^{+}\right)$, combined nitrate and nitrite $\left(\mathrm{NO}_{2+3}\right)$, dinitrogen $\left(\mathrm{N}_{2}\right)$ and soluble reactive phospho- 
rus (SRP) were determined in a pilot study (October 2009) and then seasonally (November 2009 and April, June and August 2010) using a combination of in situ equilibration with ex situ incubation and measurement. Custom-designed incubation chambers consisted of 3 primary components machined from $40.6 \mathrm{~cm}$ (16") outer diameter PVC pipe: a sampling tray (area $=0.1 \mathrm{~m}^{-2}$ ), a midsection and an upper section (Fig. 4). During each sampling period, divers deployed 8 sampling trays, one in each subplot at each site. Each tray was filled with material from the site (restored site $=$ sediments, oyster shell and oyster clumps; control site = sediments) and embedded in the substratum flush with surrounding sediments. Trays remained in the field for approximately $2 \mathrm{wk}$ to allow the system to equilibrate.
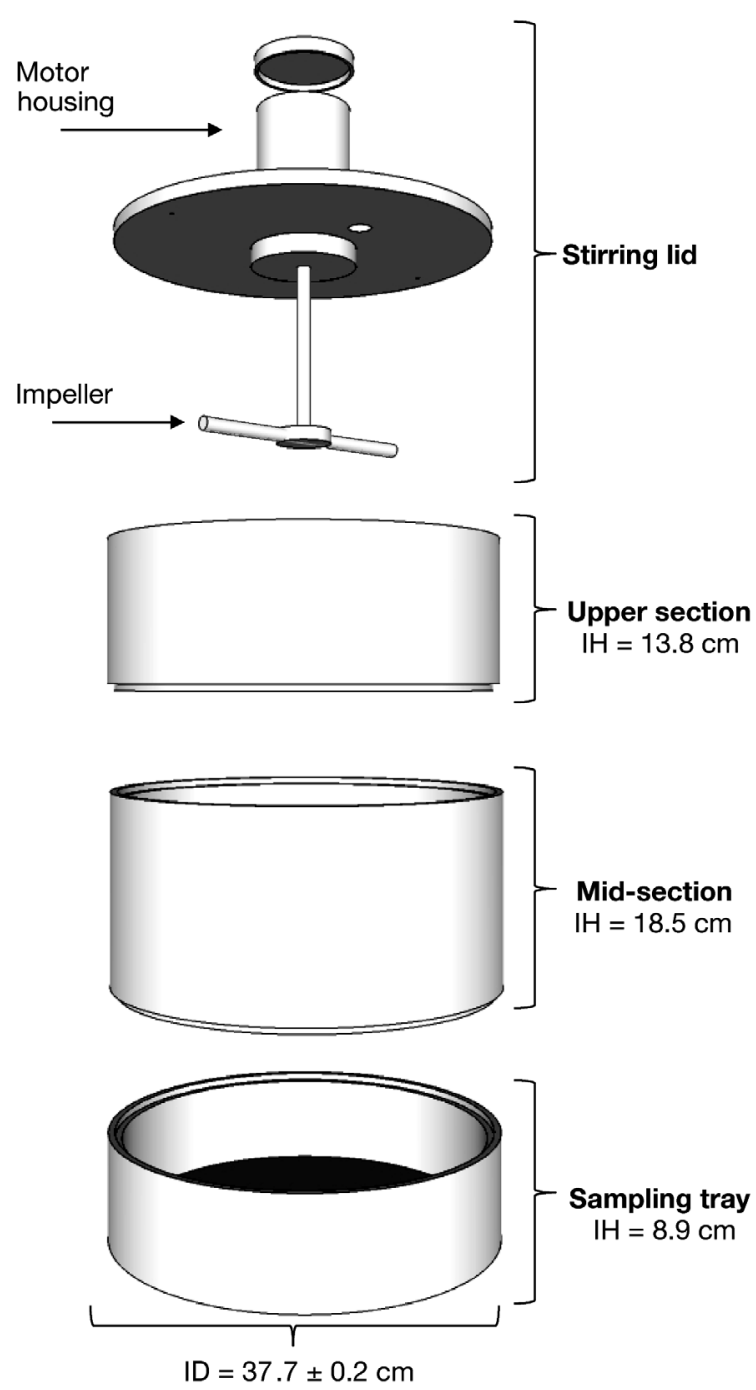

Fig. 4. Diagram of incubation chamber drawn to scale. All major components of the chambers were constructed from PVC. IH: inner height; ID: inner diameter
At the end of each field equilibration period, divers capped the sampling trays underwater by adding the chamber midsection fitted with a lid, allowing collection of reef materials, associated organisms, sediments and a portion of the overlying water column. Samples were transported to the surface and delivered to the University of Maryland Center for Environmental Science's Horn Point Laboratory (HPL) in Cambridge, Maryland, within $2.5 \mathrm{~h}$ of collection, where they were placed in a water bath (unfiltered Choptank River water with temperature adjusted to field conditions) inside an environmental chamber and aerated for $\geq 1 \mathrm{~h}$ to bring dissolved oxygen levels to saturation. During aeration, a $500 \mu \mathrm{m}$ mesh lid on each chamber prevented escape of mobile macrofauna. An additional chamber in the water bath containing only unfiltered Choptank River water served as a seawater control (hereafter 'blank'), bringing the total number of chambers sampled during each set of experiments to 9 .

Seasonal flux incubations were carried out in the dark and began $\leq 5 \mathrm{~h}$ after collection of the first sample in the field. Prior to starting incubations, mesh lids and air stones were replaced with stirring lids that sealed the sample from the surrounding water bath and mixed the water column using a motor-driven impeller (Fig. 4). Each stirring lid was fitted with a sampling tube, a water replacement tube that drew water from the water bath and a dissolved oxygen probe (NexSens Model WQ-DO). During incubations, we sampled solutes and dissolved gases a minimum of 4 times from each chamber. For the pilot study, the first incubation began $24 \mathrm{~h}$ after sample trays were collected from the field, and incubation of the trays from the restored site was repeated at 28, 48 and $73 \mathrm{~h}$ after collection. Otherwise, all incubation methods were identical between the pilot study and seasonal flux measurements. Timing of sampling events was based on real time data from oxygen probes. Total incubation periods varied seasonally from 0.8 to $2.3 \mathrm{~h}$ for samples from the restored site and from 17.0 to $24.5 \mathrm{~h}$ for samples from the control site. Because incubation periods were much shorter for samples from the restored site than for those from the control site, we were able to incubate these trays twice in succession. Between incubation periods, stirring lids were replaced with mesh lids with air stones and aerated for an hour to return oxygen levels to saturation. Final oxygen concentrations for the restored trays ranged from a low of $0.08 \pm$ $0.02 \mathrm{mmol} \mathrm{l}^{-1}$ (mean $\pm \mathrm{SD}$, here and throughout) in June to a high of $0.19 \pm 0.01 \mathrm{mmol} \mathrm{l}^{-1}$ in November. 
During each sampling event, water samples were collected for analyses of dissolved gases $\left(\mathrm{O}_{2}, \mathrm{~N}_{2}\right.$, Ar) and solutes $\left(\mathrm{NH}_{4}{ }^{+}, \mathrm{NO}_{2+3}, \mathrm{SRP}\right)$. Dissolved gas samples were preserved with $10 \mu \mathrm{l}$ of $50 \%$ saturated $\mathrm{HgCl}_{2}$, sealed, submerged in water and stored at temperatures equal to or below incubation temperatures until analysis. Solute samples were filtered (pore size $=0.45 \mu \mathrm{m}$ ) and frozen for later analysis. Dissolved gas samples were analyzed using membrane-inlet mass spectrometry (Kana et al. 1994). $\mathrm{NH}_{4}{ }^{+}$concentrations were determined using phenol/ hypochlorite colorimetry (Parsons et al. 1984). $\mathrm{NO}_{2+3}$ concentrations were determined by using automated colorimetric analysis with a detection limit of $<0.03 \mathrm{mg}$ $1^{-1}$ (Parsons et al. 1984). SRP analyses followed Parsons et al. (1984).

Fluxes for all analytes were determined using linear regressions fitted to plots of concentration $(\mathrm{n} \geq$ 4 for each chamber) versus time. To remove the influence of water column processes, slopes of regression lines were adjusted using data from the blank chamber when those data indicated significant flux of an analyte. Fluxes were considered significant when the regression line had an $R^{2} \geq 0.80$ and the difference between data in a time course was greater than the precision of the analytical method. To estimate average hourly fluxes for the year, we applied the average of the 4 measured rates to the 8 mo period from April through November, assigned zero values to the winter months and divided by 12 . This method was intentionally chosen to generate conservative estimates. To estimate the total amount of nitrogen removed via denitrification annually, we multiplied the average hourly flux by the number of hours in a year.

We estimated total remineralized nitrogen fluxes $(\Sigma \mathrm{N})$ as the sum of $\mathrm{NO}_{2+3}, \mathrm{NH}_{4}{ }^{+}$and $\mathrm{N}_{2}-\mathrm{N}$ fluxes. This method works even when $\mathrm{NO}_{2+3}$ fluxes are directed into the sediment because negative fluxes result in either denitrification or dissimilatory nitrate reduction to ammonium, both of which are captured by this calculation. Nitrification and denitrification efficiencies describe the proportion of total nitrogen remineralization resulting from nitrification and denitrification, respectively. We did not measure nitrification directly, but calculated it from the sum of the $\mathrm{NO}_{2+3}$ and $\mathrm{N}_{2}-\mathrm{N}$ fluxes to the water column. Thus, nitrification efficiency can be expressed as:

Nitrification Efficiency $(\%)=\frac{\left(\mathrm{N}_{2}-\mathrm{N}\right)+\left(\mathrm{NO}_{2+3}\right)}{\Sigma \mathrm{N}} \times 100$

where $\mathrm{N}_{2}-\mathrm{N}$ is di-nitrogen flux, $\mathrm{NO}_{2+3}$ is combined nitrate and nitrite flux and $\Sigma \mathrm{N}$ is total inorganic nitrogen flux.
Similarly, denitrification efficiency can be expressed as:

$$
\text { Denitrification Efficiency }(\%)=\frac{\mathrm{N}_{2}-\mathrm{N}}{\Sigma \mathrm{N}} \times 100
$$

To examine nutrient fluxes relative to organic matter oxidation, we calculated the stoichiometric ratios of $\mathrm{C}: \mathrm{N}: \mathrm{P}$ for each set of samples collected and compared them to the expected Redfield ratio of 106C:16N:1P for marine algae. Although we were unable to measure carbon remineralization during each sampling period, we did measure $\mathrm{O}_{2}$ flux on each occasion. Assuming the primary drivers of oxygen demand in our system were metazoan respiration, aerobic microbial respiration and the reoxidation of reduced species resulting from alternate terminal electron acceptors [i.e. Fe(II), $\mathrm{H}_{2} \mathrm{~S}$ ], we used an $\mathrm{O}_{2}: \mathrm{CO}_{2}$ flux ratio of $1: 1$ to estimate total carbon mineralization. Because SRP is the product of organic phosphorus remineralization, fluxes of SRP were used directly to estimate phosphorus remineralization. Ratios of C:N:P were estimated using regression lines fitted to measured seasonal fluxes of SRP versus $\Sigma \mathrm{N}, \Sigma \mathrm{N}$ versus $\mathrm{O}_{2}$ and SRP versus $\mathrm{O}_{2}$.

\section{Macrofaunal abundance, biomass and nutrient content}

We compared nutrient assimilation into macrobenthic organisms between restored and control sites by estimating the average standing stock of assimilated nutrients at each site using the samples collected for seasonal flux incubations. At the end of each incubation, material in each sampling tray was rinsed through a sieve series (mesh sizes: 12.5, 4.0 and $1.0 \mathrm{~mm}$ ) and all organisms $>1.0 \mathrm{~mm}$ were retained. Whenever possible, we retained a minimum of 25 individuals from each major faunal group from each tray for nutrient analyses. To collect organisms attached to or living within large shells and shell fragments, all materials retained on the $12.5 \mathrm{~mm}$ sieve were further processed by (1) removing all macrofauna visible to the naked eye, (2) gently scrubbing all surfaces with a soft brush, (3) reexamining materials under $1.75 \times$ magnification, (4) soaking in successive freshwater baths until no additional organisms were recovered from the bathwater $(\sim 2$ to $3 \mathrm{~h})$ and (5) carefully destroying materials to remove any organisms retained within them. In November, the shells of all live oysters were broken apart to remove organisms. With the exception of one tray in April which contained only 3 live oysters, 
Table 1. Dates of deployment for each sampling period and environmental conditions during deployment (mean \pm SD). Data were collected at 5 min intervals throughout the deployment period. Data for salinity and dissolved oxygen (DO) are not reported for the control site during the November sampling period due to sonde malfunction

\begin{tabular}{|c|c|c|c|c|c|c|c|}
\hline \multirow{2}{*}{$\begin{array}{l}\text { Sampling } \\
\text { period }\end{array}$} & \multirow{2}{*}{$\begin{array}{c}\text { Deployment } \\
\text { period }\end{array}$} & \multicolumn{2}{|c|}{ Average temperature $\left({ }^{\circ} \mathrm{C}\right)$} & \multicolumn{2}{|c|}{ Average salinity (ppt) } & \multicolumn{2}{|c|}{ Average DO $\left(\mathrm{mg} \mathrm{l}^{-1}\right)$} \\
\hline & & Control & Restored & Control & Restored & Control & Restored \\
\hline Nov & 29 Oct-10 Nov 2009 & $14.5 \pm 1.0$ & $14.5 \pm 1.0$ & & $11.6 \pm 0.9$ & & $7.8 \pm 0.6$ \\
\hline Apr & 6-20 Apr 2010 & $15.2 \pm 0.9$ & $15.1 \pm 1.0$ & $6.8 \pm 0.7$ & $7.0 \pm 0.7$ & $7.0 \pm 1.4$ & $6.9 \pm 1.2$ \\
\hline Jun & 7-21 Jun 2010 & $26.0 \pm 0.7$ & $25.7 \pm 0.6$ & $7.6 \pm 0.3$ & $8.2 \pm 0.4$ & $6.1 \pm 0.7$ & $5.4 \pm 0.7$ \\
\hline Aug & 10-26 Aug 2010 & $27.8 \pm 0.8$ & $27.8 \pm 0.7$ & $9.5 \pm 0.3$ & $10.1 \pm 0.4$ & $5.9 \pm 0.7$ & $5.2 \pm 0.8$ \\
\hline
\end{tabular}

5 live oysters were randomly selected from each tray in April, June and August for analyses of barnacle abundance. All oysters and mussels collected from the $\geq 12.5 \mathrm{~mm}$ size fraction were frozen for later analyses. All other organisms retained on sieves $\geq 1.0 \mathrm{~mm}$ were preserved in $10 \%$ buffered formalin for $\geq 48 \mathrm{~h}$ followed by rinsing and transfer to $70 \%$ ethanol.

All organisms collected from sampling trays were counted (using subsampling as needed), identified to the lowest practical taxonomic level, dried to constant weight at $60^{\circ} \mathrm{C}$ and weighed to the nearest $0.1 \mathrm{mg}$. Samples from each major faunal group were ground to a fine powder using a mortar and pestle prior to nutrient analyses. Nitrogen was analyzed with an automated CHN analyzer, and phosphorus was analyzed by extraction of $\mathrm{P}$ from combusted samples using $1 \mathrm{~N} \mathrm{HCl}$ followed by colorimetric analyses (Aspila et al. 1976). When sufficient material existed, 3 replicates were analyzed from each faunal group. The total amount of nitrogen and phosphorus assimilated was determined by multiplying the total dry weight of each group by its percentage of nitrogen and phosphorus. For mussels and oysters $>10 \mathrm{~mm}$ in shell height, shells and soft tissue were analyzed separately. For some groups, replicate analyses were made for different components of the sample (e.g. gravid versus non-gravid xanthid crabs), and total nutrient content was calculated using a weighted mean percentage based on the abundance and biomass of each component. Because estimating secondary production rates was beyond the scope of this project, seasonal standing stock assimilation values were averaged to estimate annual standing stocks of assimilated nitrogen $\left(\mathrm{TN}_{\mathrm{ss}}\right)$ and phosphorus $\left(\mathrm{TP}_{\mathrm{ss}}\right)$ at each site and do not represent an annual rate of assimilation. During the course of sampling and sample processing, we observed nothing to suggest that the presence of trays significantly impacted macrofaunal abundance, biomass, or behavior.

\section{RESULTS}

Differences in environmental conditions between the restored and control sites were minor and well below values we consider biologically significant (Table 1). In contrast, sites differed significantly in the total sediment volume in sampling trays (restored site $=6.4 \pm 1.5 \mathrm{l}$, control site $=4.4 \pm 1.1 \mathrm{l}$ ) and sediment characteristics (Table 2). Sediments at the restored site had lower median grain size and higher organic content. Percentages of total carbon, organic carbon, total nitrogen and total phosphorus per gram dry weight (DW) of sediments were an order of magnitude higher at the restored site than at the control site.

\section{Biogeochemical fluxes}

The pilot study was instructive for examining the trajectory of incubations over a short period of time. Over the $2 \mathrm{~d}$ period we measured nitrogen fluxes, ammonium fluxes steadily decreased, with net ammonium uptake exhibited on the third day (Fig. 5). During the same time period, $\mathrm{NO}_{2+3}$ fluxes and, to a much lesser extent, $\mathrm{N}_{2}-\mathrm{N}$ fluxes increased.

Table 2. Sediment characteristics at the control and restored sites in August. Data are reported as means \pm SD

\begin{tabular}{|lcc|}
\hline \multirow{2}{*}{$\begin{array}{l}\text { Sediment } \\
\text { characteristics }\end{array}$} & Control $(\mathrm{n}=4)$ & Restored $(\mathrm{n}=3)$ \\
\hline Median grain size $(\mu \mathrm{m})$ & $457.2 \pm 30.4$ & $25.5 \pm 22.6$ \\
Sand $(\%)$ & $97.3 \pm 1.9$ & $37.0 \pm 12.4$ \\
Total organics (\%) & $0.7 \pm 0.3$ & $10.8 \pm 3.1$ \\
Total carbon (\%) & $0.418 \pm 0.074$ & $6.533 \pm 0.676$ \\
Organic carbon (\%) & $0.360 \pm 0.053$ & $4.196 \pm 0.561$ \\
Total nitrogen (\%) & $0.028 \pm 0.011$ & $0.333 \pm 0.040$ \\
Total phosphorus $(\%)$ & $0.009 \pm 0.002$ & $0.082 \pm 0.005$ \\
& & \\
\hline
\end{tabular}


Respiration rates for the restored site were high (Fig. 6), with oxygen demand ranging from $12.87 \pm$ $1.61 \mathrm{mmol} \mathrm{O}_{2} \mathrm{~m}^{-2} \mathrm{~h}^{-1}$ in November to $38.82 \pm$ $4.35 \mathrm{mmol} \mathrm{O}_{2} \mathrm{~m}^{-2} \mathrm{~h}^{-1}$ in June. Oxygen demand for the control site was much lower, ranging from 1.14 $\pm 0.32 \mathrm{mmol} \mathrm{O} \mathrm{m}^{-2} \mathrm{~h}^{-1}$ in August to $1.54 \pm 0.17$ mmol $\mathrm{O}_{2} \mathrm{~m}^{-2} \mathrm{~h}^{-1}$ in April. Average hourly oxygen demand was 20 times higher for the restored site (17.80 mmol $\mathrm{O}_{2} \mathrm{~m}^{-2} \mathrm{~h}^{-1}$ ) than for the control site (0.91 mmol $\mathrm{O}_{2} \mathrm{~m}^{-2} \mathrm{~h}^{-1}$ ). Oxygen demand was positively correlated with bottom water temperature $\left(\mathrm{R}^{2}\right.$ $=0.99$ ) for the restored site, but not for the control site $\left(\mathrm{R}^{2}=0.34\right)$.

Similar seasonality was observed for the release of ammonium from the sediments into the water column
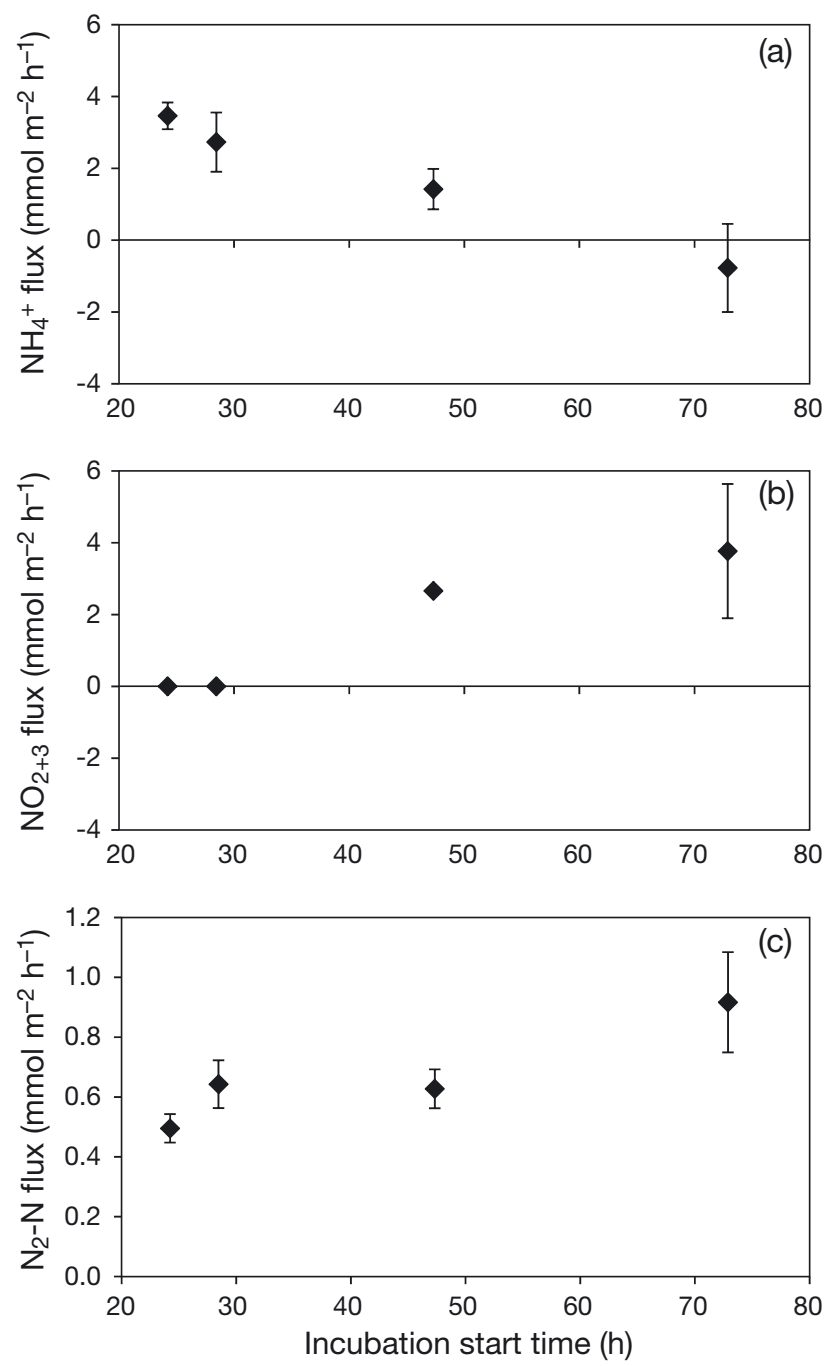

Fig. 5. Changes $( \pm \mathrm{SD})$ in (a) $\mathrm{NH}_{4}{ }^{+}$flux, (b) $\mathrm{NO}_{2+3}$ and (c) $\mathrm{N}_{2}-\mathrm{N}$ flux over time with repeated incubations in October $(\mathrm{n}=4$ except for the incubation at $24 \mathrm{~h}$ where $\mathrm{n}=3$ ). Negative values represent fluxes from the water column to the benthos at the restored site (Fig. 7a). Ammonium fluxes for the restored site ranged from $0.62 \pm 0.10 \mathrm{mmol} \mathrm{NH}_{4}{ }^{+}$ $\mathrm{m}^{-2} \mathrm{~h}^{-1}$ in November to $3.51 \pm 0.45 \mathrm{mmol} \mathrm{NH}_{4}^{+} \mathrm{m}^{-2}$ $\mathrm{h}^{-1}$ in August, while those at the control site were much lower, ranging from $0.05 \pm 0.07 \mathrm{mmol} \mathrm{NH}_{4}{ }^{+} \mathrm{m}^{-2}$ $\mathrm{h}^{-1}$ in June to $0.12 \pm 0.05 \mathrm{mmol} \mathrm{NH}_{4}^{+} \mathrm{m}^{-2} \mathrm{~h}^{-1}$ in August. Average hourly ammonium flux for the restored site $\left(1.24 \mathrm{mmol} \mathrm{NH}_{4}^{+} \mathrm{m}^{-2} \mathrm{~h}^{-1}\right)$ was 23 times greater than that for the control site $\left(0.05 \mathrm{mmol} \mathrm{NH}_{4}^{+}\right.$ $\left.\mathrm{m}^{-2} \mathrm{~h}^{-1}\right)$.

Fluxes of combined nitrate and nitrite for the restored site also peaked in late summer and were much higher than values for the control site (Fig. 7b). Fluxes for the restored site ranged from $0.46 \pm 0.07 \mathrm{mmol}$ $\mathrm{NO}_{2+3} \mathrm{~m}^{-2} \mathrm{~h}^{-1}$ in November to $1.83 \pm 0.11 \mathrm{mmol} \mathrm{NO}_{2+3}$ $\mathrm{m}^{-2} \mathrm{~h}^{-1}$ in August compared to control site fluxes ranging from $0.01 \pm 0.02 \mathrm{mmol} \mathrm{NO}_{2+3} \mathrm{~m}^{-2} \mathrm{~h}^{-1}$ in April to $0.07 \pm 0.01 \mathrm{mmol} \mathrm{NO}_{2+3} \mathrm{~m}^{-2} \mathrm{~h}^{-1}$ in August. Average hourly $\mathrm{NO}_{2+3}$ flux for the restored site was $0.72 \mathrm{mmol}$ $\mathrm{NO}_{2+3} \mathrm{~m}^{-2} \mathrm{~h}^{-1}$ compared to $0.02 \mathrm{mmol} \mathrm{NO} \mathrm{NO}_{2+3} \mathrm{~m}^{-2} \mathrm{~h}^{-1}$ for the control site, reflecting high rates of nitrification in the reef environment.

Denitrification rates (estimated from fluxes of $\mathrm{N}_{2}-\mathrm{N}$ ) for the restored site were highest in August $\left(1.59 \pm 0.22 \mathrm{mmol} \mathrm{N}_{2}-\mathrm{N} \mathrm{m}^{-2} \mathrm{~h}^{-1}\right)$ and lowest in November $\left(0.25 \pm 0.06 \mathrm{mmol} \mathrm{N}_{2}-\mathrm{N} \mathrm{m}^{-2} \mathrm{~h}^{-1}\right.$; Fig. $\left.7 \mathrm{c}\right)$. Again, rates for the control site were much lower, ranging from $0.04 \pm 0.01 \mathrm{mmol} \mathrm{N}_{2}-\mathrm{N} \mathrm{m}^{-2} \mathrm{~h}^{-1}$ in April to $0.11 \pm$ $0.02 \mathrm{mmol} \mathrm{N}_{2}-\mathrm{N} \mathrm{m}^{-2} \mathrm{~h}^{-1}$ in August. Average hourly $\mathrm{N}_{2}-\mathrm{N}$ flux for the restored site $\left(0.50 \mathrm{mmol} \mathrm{N}_{2}-\mathrm{N} \mathrm{m}^{-2}\right.$ $\mathrm{h}^{-1}$ ) was 12 times greater than for the control site

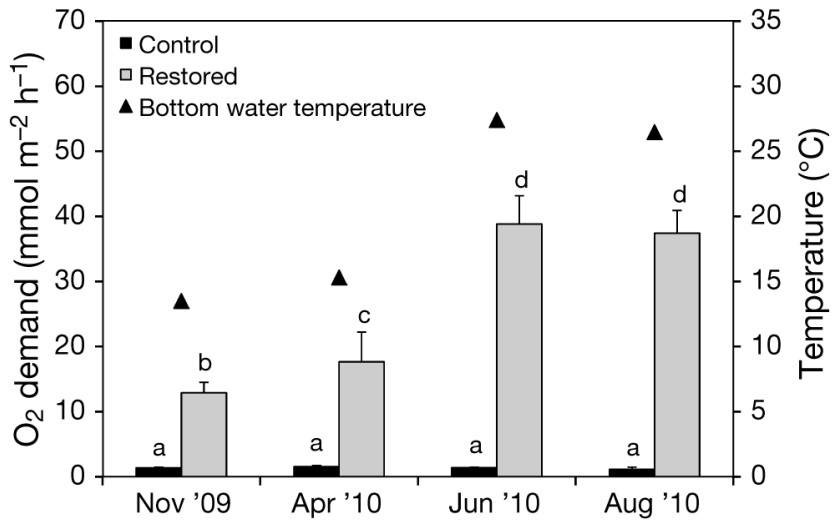

Fig. 6. Seasonal fluxes of oxygen (= sediment oxygen demand; left axis) and bottom water temperature (right axis). Error bars represent 1 standard deviation ( $\mathrm{n}=4$ except for the restored site in August where $\mathrm{n}=3$ ). Two-way ANOVA indicated a significant interaction between site and season $(p<0.001)$. Letters are used to indicate significant differences between levels within each main effect based upon 1way ANOVA followed by Tukey's post hoc comparison $(\alpha=$ $0.05)$. Bars that share a letter are not significantly different 

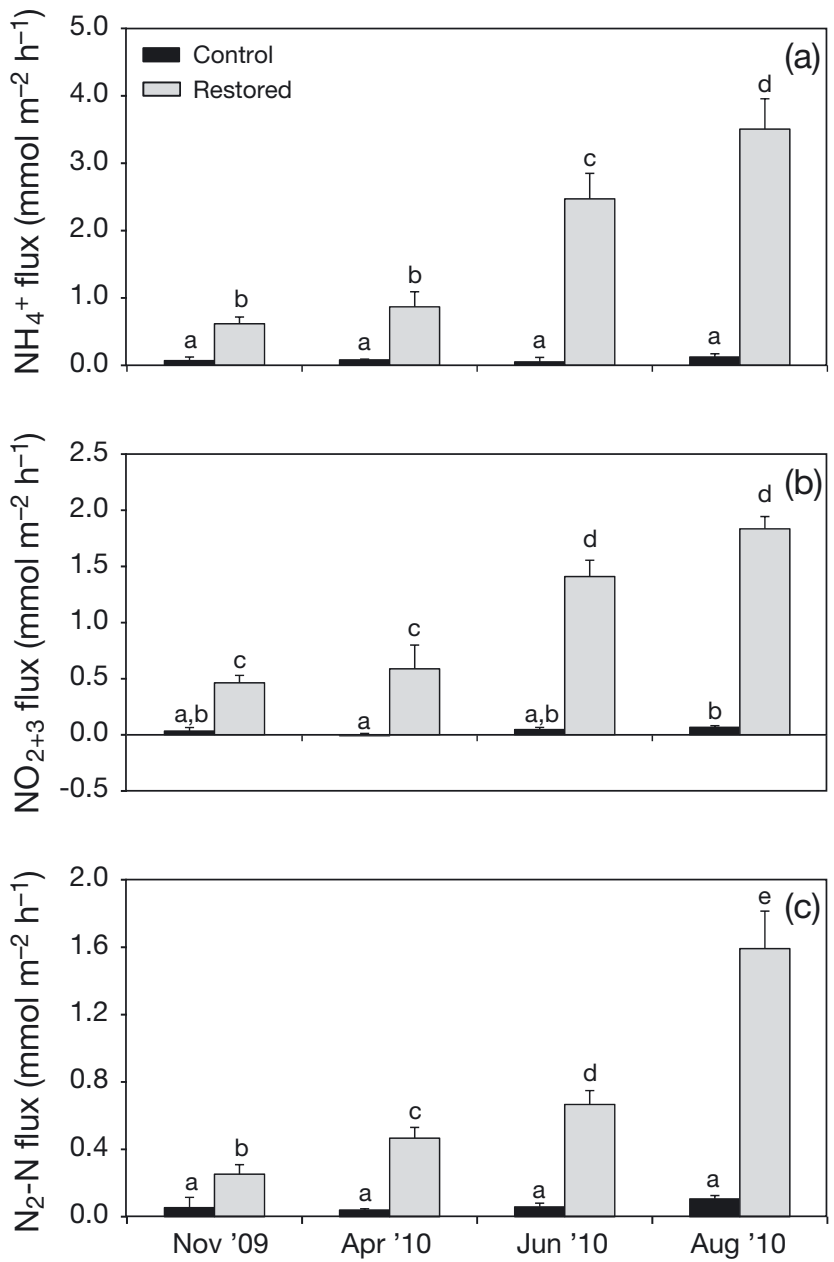

Fig. 7. Seasonal fluxes of (a) $\mathrm{NH}_{4}{ }^{+}$, (b) $\mathrm{NO}_{2+3}$ and (c) $\mathrm{N}_{2}-\mathrm{N}$. Error bars represent 1 standard deviation $(\mathrm{n}=4$ except for the restored site in August where $n=3$ ). Negative values represent fluxes from the water column to the benthos. Twoway ANOVA indicated a significant interaction between site and season for all 3 analytes ( $<<0.001)$. Letters are used to indicate significant differences between levels within each main effect based upon 1-way ANOVA followed by Tukey's post hoc comparison $(\alpha=0.05)$. Bars that share a letter are not significantly different

$\left(0.04 \mu \mathrm{mol} \mathrm{N} \mathrm{N}_{2}-\mathrm{N} \mathrm{m}^{-2} \mathrm{~h}^{-1}\right)$. Estimated annual removal for the restored site was $61 \mathrm{~g} \mathrm{~N} \mathrm{~m}^{-2} \mathrm{yr}^{-1}$ compared to $5 \mathrm{~g} \mathrm{~N} \mathrm{~m}^{-2} \mathrm{yr}^{-1}$ for the control site.

Patterns in SRP flux were similar to those observed for ammonium (Fig. 8), increasing at the restored site from 0.09 to $0.20 \mathrm{mmol} \mathrm{P} \mathrm{m}^{-2} \mathrm{~h}^{-1}$ during the first 3 sampling periods to $0.57 \mathrm{mmol} \mathrm{m}^{-2} \mathrm{~h}^{-1}$ in August. SRP fluxes were significantly lower for the control site than for the restored site in all seasons, ranging from -0.01 to $0.02 \mathrm{mmol} \mathrm{m}^{-2} \mathrm{~h}^{-1}$. Average hourly SRP flux at the restored site was $0.16 \mathrm{mmol} \mathrm{m}^{-2} \mathrm{~h}^{-1} \mathrm{com}$ pared to $0.00 \mathrm{mmol} \mathrm{m}^{-2} \mathrm{~h}^{-1}$ at the control site.

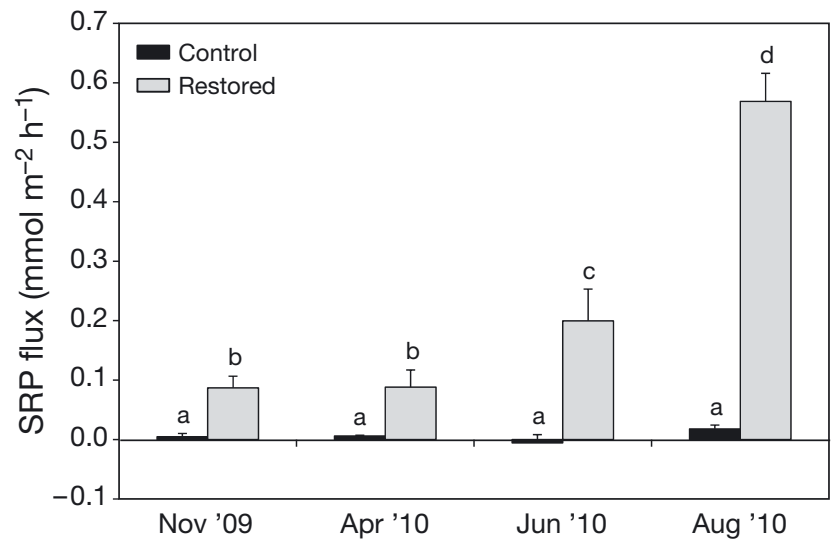

Fig. 8. Seasonal fluxes of soluble reactive phosphorus (SRP). Error bars represent 1 standard deviation ( $\mathrm{n}=4$ except for the restored site in August where $n=3$ ). Negative values represent fluxes from the water column to the benthos. Twoway ANOVA indicated a significant interaction between site and season $(p<0.001)$. Letters are used to indicate significant differences between levels within each main effect based upon 1-way ANOVA followed by Tukey's post hoc comparison $(\alpha=0.05)$. Bars that share a letter are not significantly different

For the restored site, total nitrogen fluxes ranged from $1.33 \pm 0.11$ to $6.93 \pm 0.27 \mathrm{mmol} \mathrm{N} \mathrm{m}^{-2} \mathrm{~h}^{-1} \mathrm{com}-$ pared to only $0.11 \pm 0.02$ to $0.30 \pm 0.07 \mathrm{mmol} \mathrm{N} \mathrm{m}^{-2}$ $\mathrm{h}^{-1}$ for the control site (Fig. 9a). Nitrogen flux from the restored site was dominated by ammonium, corresponding to high rates of respiration and consequent nitrogen remineralization.

Nitrification efficiencies for the restored site ranged from $46 \pm 4 \%$ in June to $55 \pm 5 \%$ in April and those for the control site ranged from $33 \pm 4 \%$ in April to $76 \pm 20 \%$ in June (Fig. 9b). Nitrification efficiencies were significantly higher for the restored site than for the control site samples in April, but this pattern had reversed by June. Season did not significantly influence efficiencies at the restored site, but did have an impact at the control site.

Denitrification efficiencies for the restored site ranged from $15 \pm 2 \%$ in June to $25 \pm 7 \%$ in April and those for the control site ranged from $17 \pm 17 \%$ in November to $42 \pm 15 \%$ in June (Fig. 9c). June was the only sampling period in which there was a significant difference between sites. Although season had no effect at the restored site, denitrification efficiencies were significantly higher in June than in November or April at the control site.

Using data from all of our samples $(\mathrm{n}=31)$, regression lines were fitted to fluxes of SRP versus $\Sigma \mathrm{N}, \Sigma \mathrm{N}$ versus $\mathrm{O}_{2}$, and SRP versus $\mathrm{O}_{2}$, resulting in ratios of $15 \mathrm{P}: 1 \mathrm{~N}, 7 \mathrm{O}_{2}: 1 \mathrm{~N}$ and $116 \mathrm{O}_{2}: 1 \mathrm{P}$, respectively (Fig. 10). Using a 1:1 ratio of $\mathrm{O}_{2}: \mathrm{CO}_{2}$ resulted in a $\mathrm{C}: \mathrm{N}: \mathrm{P}$ ratio of 116:15:1. 

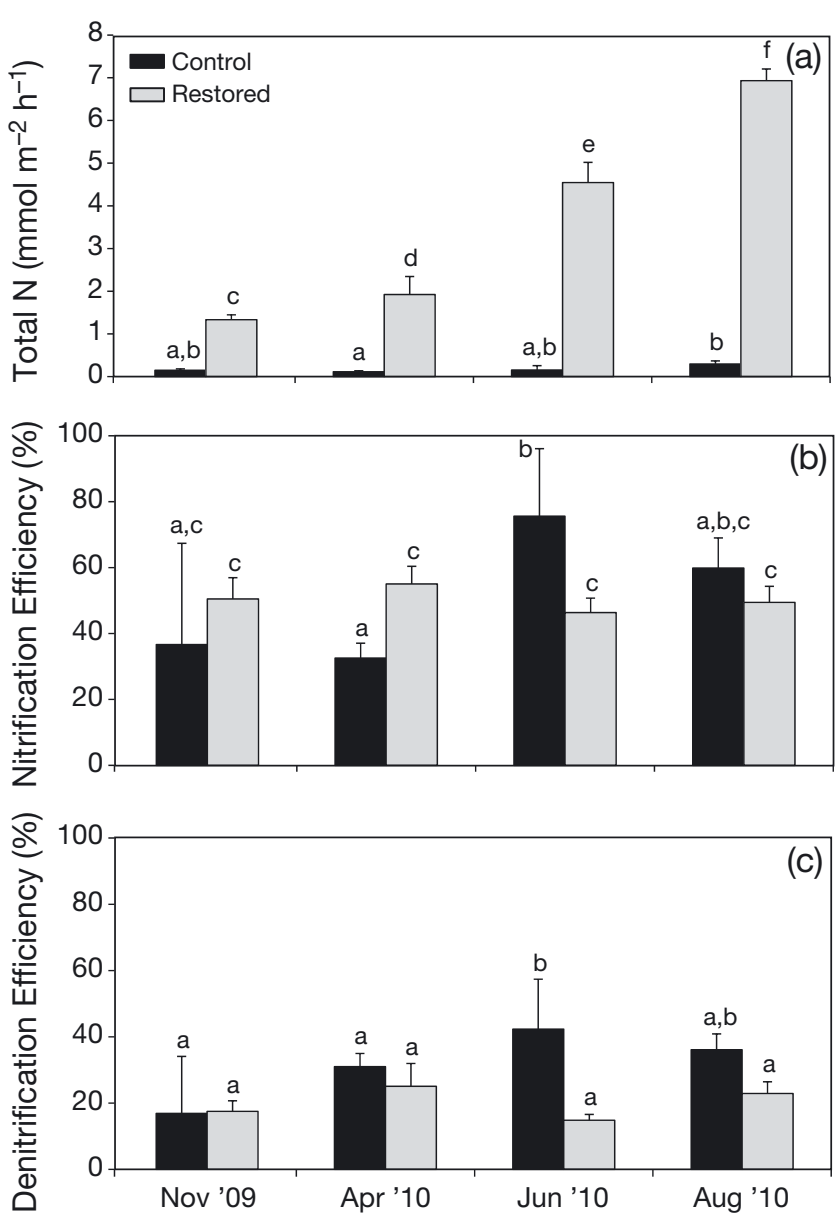

Fig. 9. (a) Total inorganic nitrogen fluxes, and (b) efficiency of nitrification and (c) denitrification for control and restored sites. Error bars represent 1 standard deviation (for total nitrogen, $\mathrm{n}=4$ except for the restored site in August where $\mathrm{n}=$ 3 ; for efficiencies, $\mathrm{n}=4$ except for the restored site in August and the control site in November and April where $n=3$ ). In all cases, 2-way ANOVAs indicated a significant interaction between site and season (total nitrogen: $p<0.001$; denitrification: $p=0.030$; nitrification: $p=0.005$ ). Letters are used to indicate significant differences between levels within each main effect based upon 1-way ANOVA followed by Tukey's post hoc comparison $(\alpha=0.05)$. Bars that share a letter are not significantly different

\section{Macrofaunal abundance, biomass and nutrient content}

Prior to completion of macrofaunal abundance and biomass analyses, a laboratory fire resulted in the loss of some samples from the restored site. As a result, reported abundance and biomass values for barnacles and biomass values for crabs underestimate actual values.

Macrofaunal abundances were higher in samples from the restored site than from the control site for all organisms except clams (Table 3). The 3 -fold greater
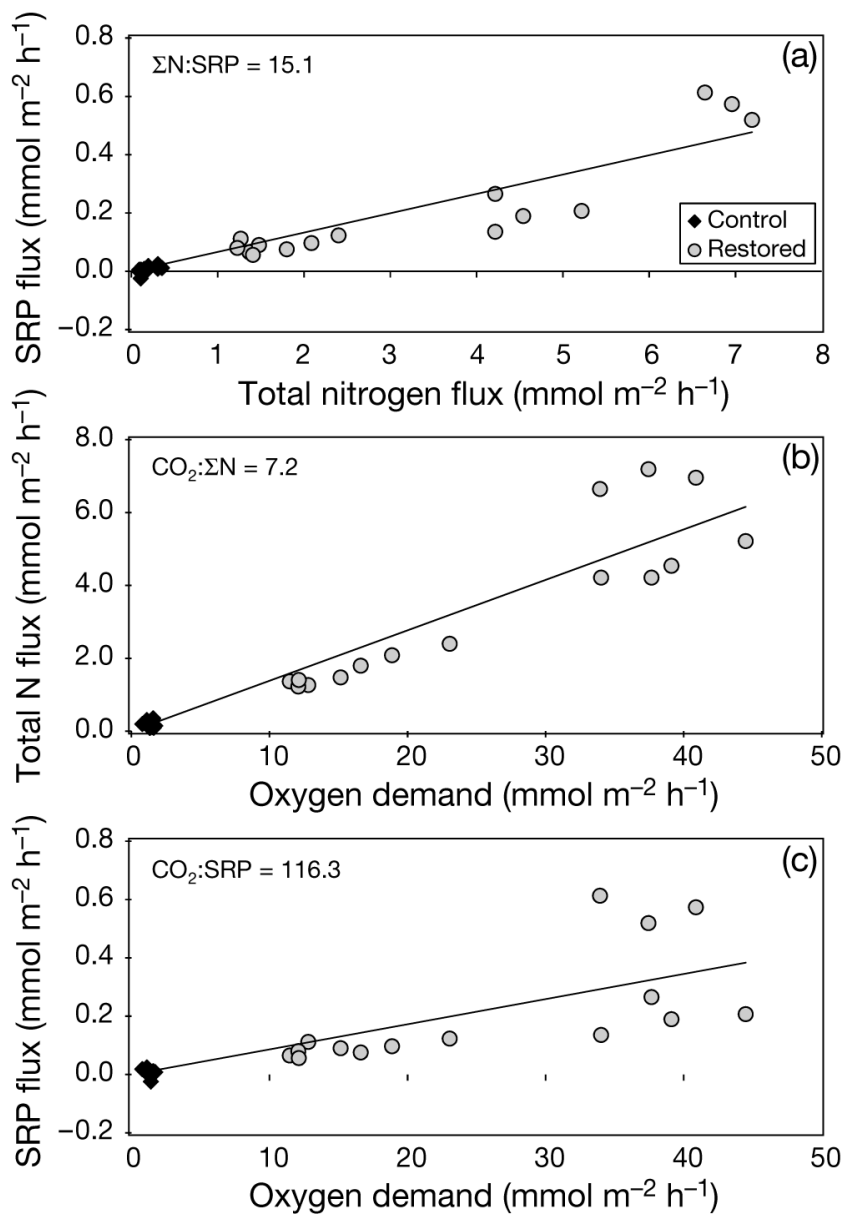

Fig. 10. Stoichiometric plots using all individual core fluxes of $\mathrm{O}_{2}, \Sigma \mathrm{N}$ (sum of $\mathrm{NH}_{4}{ }^{+}, \mathrm{NO}_{2+3}$ and $\mathrm{N}_{2}-\mathrm{N}$ ) and SRP. We assume that the stoichiometric ratio of $\mathrm{CO}_{2}: \mathrm{O}_{2}$ during decomposition was $1: 1$; this implies that the reduced products of anaerobic decomposition were reoxidized. (a) $\Sigma \mathrm{N}$ :SRP ratio was 15 , (b) $\mathrm{CO}_{2}: \Sigma \mathrm{N}$ was 7 and (c) $\mathrm{CO}_{2}$ :SRP was 116 , yielding a $\mathrm{C}: \mathrm{N}: \mathrm{P}$ of $116: 15: 1$, similar to the Redfield elemental ratio for marine algae $(106: 16: 1)$

average abundance of clams at the control site was driven by high abundances of small clams $(<10 \mathrm{~mm})$, especially in the April and June sampling periods $\left(3317 \pm 875\right.$ and $1638 \pm 584$ ind. $\mathrm{m}^{-2}$, respectively) Among the other major faunal groups, sessile species were either completely absent or 2 orders of magnitude less abundant at the control site than at the restored site. Greatest differences among mobile species were found for polychaete worms and xanthid crabs, which were also 2 orders of magnitude less abundant at the control site.

Macrofaunal biomass (inclusive of shell) was greater at the restored site than at the control site for all faunal groups (Table 3 ). Although $86 \%$ of this difference in biomass between sites can be attributed to oysters, the restored site also had $2564 \pm 634 \mathrm{~g} \mathrm{~m}^{-2}$ 
Table 3. Average abundance and biomass (inclusive of shell) of major faunal groups from restored and control sites. Numerical and/or biomass dominant species listed in parentheses under each faunal group. DW: dry weight

\begin{tabular}{|c|c|c|c|c|}
\hline \multirow[t]{2}{*}{ Faunal group } & \multicolumn{2}{|c|}{ Abundance (ind. $\mathrm{m}^{-2}, \pm \mathrm{SD}$ ) } & \multicolumn{2}{|c|}{ Biomass (g DW m ${ }^{-2}, \pm \mathrm{SD}$ ) } \\
\hline & Control & Restored & Control & Restored \\
\hline $\begin{array}{l}\text { Amphipods } \\
\text { (Melita nitida, Apocorophium lacustre, Apocorophiv }\end{array}$ & $\begin{array}{l}340.6 \pm 558.4 \\
\text { Im simile) }\end{array}$ & $7067.3 \pm 1847.0$ & $0.3 \pm 0.5$ & $3.5 \pm 3.7$ \\
\hline $\begin{array}{l}\text { Anemones } \\
\text { (Diadumene leucolena) }\end{array}$ & $0 \pm 0$ & $893.8 \pm 1279.3$ & $0 \pm 0$ & $5 \pm 8.8$ \\
\hline 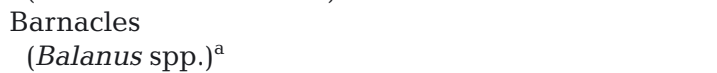 & $0 \pm 0$ & $3769.6 \pm 3552.8$ & $0 \pm 0$ & $110.7 \pm 91.4$ \\
\hline $\begin{array}{l}\text { Clams } \\
\text { (Mya arenaria, Macoma balthica, Mulinia lateralis) }\end{array}$ & $1456.4 \pm 1372.9$ & $481.4 \pm 726.2$ & $10.8 \pm 12.3$ & $57.8 \pm 56.9$ \\
\hline $\begin{array}{l}\text { Crabs } \\
\text { (Eurypanopeus depressus) }^{\mathrm{a}}\end{array}$ & $6.2 \pm 6.5$ & $217.7 \pm 46.1$ & $0.2 \pm 0.3$ & $87.5 \pm 79.2$ \\
\hline $\begin{array}{l}\text { Fish } \\
\text { (Gobiosoma bosc, Opsanus tau) }\end{array}$ & $10.7 \pm 14.9$ & $141.4 \pm 85.8$ & $0.3 \pm 0.3$ & $18.6 \pm 12.8$ \\
\hline $\begin{array}{l}\text { Mussels } \\
\text { (Ischadium recurvum) }\end{array}$ & $13 \pm 10.8$ & $1563.3 \pm 573$ & $0.2 \pm 0.2$ & $2279.2 \pm 598.3$ \\
\hline $\begin{array}{l}\text { Polychaete worms } \\
\text { (Alitta succinea) }\end{array}$ & $435.1 \pm 149.9$ & $10415.3 \pm 3001.1$ & $0.4 \pm 0.1$ & $12.1 \pm 3.8$ \\
\hline $\begin{array}{l}\text { Shrimp } \\
\text { (Palaemonetes pugio) }\end{array}$ & $2.8 \pm 3.3$ & $35.1 \pm 47.1$ & $0 \pm 0.1$ & $1.5 \pm 1.6$ \\
\hline Non-oyster macrofauna & $2264.9 \pm 1952.4$ & $24584.9 \pm 5921.6$ & $12.1 \pm 12.6$ & $2575.8 \pm 634.3$ \\
\hline $\begin{array}{l}\text { Oysters } \\
\text { (Crassostrea virginica) }\end{array}$ & $0 \pm 0$ & $130.7 \pm 15$ & $0 \pm 0$ & $15422.2 \pm 1505.8$ \\
\hline Total macrofauna & $2264.9 \pm 1952.4$ & $2415.6 \pm 5936.1$ & $12.1 \pm 12.6$ & $17998.0 \pm 2021.0$ \\
\hline
\end{tabular}

more non-oyster biomass than the control site. Much of this difference was driven by sessile organisms attached to oyster shells, but the biomasses of most mobile faunal groups were also 2 orders of magnitude greater for the restored site. Clam biomass was $>5$ times higher for the restored site than the control site, a difference primarily attributable to the larger average size of Mya arenaria for the restored site.

Percentages of nitrogen and phosphorus in major faunal groups and their components (e.g. oyster shell and oyster tissue) generally followed expected patterns, with highest values found in organisms without significant calcium carbonate structures (Table 4). The restored site average standing stock of nutrients was greater than that at the control site by $95.09 \pm$ $14.55 \mathrm{~g} \mathrm{~N} \mathrm{~m}^{-2}$ and $15.17 \pm 2.46 \mathrm{~g} \mathrm{P} \mathrm{m}^{-2}$, primarily due to assimilation by bivalves. Oysters (tissue + shell) accounted for 65 and $67 \%$ of $\mathrm{TN}_{\mathrm{ss}}$ and $\mathrm{TP}_{\mathrm{ss}}$, respectively (Table 5). Mussels, the second largest contributor, accounted for $25 \%$ of $\mathrm{TN}_{\mathrm{ss}}$ and $17 \%$ of $\mathrm{TP}_{\mathrm{ss}}$. When combined, the shells of live oysters and mussels $>10 \mathrm{~mm}$ accounted for $47 \%$ of $\mathrm{TN}_{\mathrm{ss}}$ and $48 \%$ of $\mathrm{TP}_{\mathrm{ss}}$. Of the other organisms found at the restored site, only fish and crabs accounted for $>1 \%$ of $\mathrm{TN}_{\mathrm{ss}}$ and $\mathrm{TP}_{\mathrm{ss}}$. Xanthid crabs contained $4 \% \mathrm{TN}_{\mathrm{ss}}$ and $8 \%$ of $\mathrm{TP}_{\mathrm{ss}}$. Fish contributed 2 and $4 \%$, of $\mathrm{TN}_{\mathrm{ss}}$ and phos- phorus, respectively. Together, non-oyster macrofauna at the restored site contained $35 \%$ of $\mathrm{TN}_{\mathrm{ss}}$ and $33 \%$ of $\mathrm{TP}_{\mathrm{ss}}$.

Table 4. Percentages of nitrogen (N) and phosphorus (P) in tissues and shell of major faunal groups. Sample size (n) is the number of samples analyzed. Because it was necessary to pool individual organisms for many analyses, the total number of individuals per sample ranged from 1 to 90

\begin{tabular}{|lccl|}
\hline Faunal group & $\mathrm{n}$ & $\mathrm{N}(\%, \pm \mathrm{SD})$ & $\mathrm{P}(\%, \pm \mathrm{SD})$ \\
\hline Amphipods & 4 & $4.53 \pm 0.58$ & $1.99 \pm 0.07$ \\
Anemones & 3 & $9.17 \pm 0.13$ & $1.33 \pm 0.07$ \\
Barnacles & 4 & $0.99 \pm 0.16$ & $0.14 \pm 0.03$ \\
Clams-mixed spp. & 6 & $1.42 \pm 0.38$ & $0.10 \pm 0.03$ \\
Clams-Mya spp. & 6 & $2.38 \pm 0.29$ & $0.28 \pm 0.06$ \\
Crabs-gravid & 3 & $4.15 \pm 0.71$ & $1.40 \pm 0.12$ \\
Crabs-not gravid & 6 & $3.98 \pm 0.65$ & $1.37 \pm 0.33$ \\
Fish-blennies & 2 & 10.86 & 3.84 \\
Fish-gobies & 6 & $10.60 \pm 0.11$ & $3.61 \pm 0.30$ \\
Fish-skilletfish & 1 & 9.37 & 4.59 \\
Fish-toad fish & 1 & 11.04 & 3.66 \\
Mussels-shell & 4 & $0.47 \pm 0.04$ & $0.04 \pm 0.01$ \\
Mussels-tissue & 4 & $10.93 \pm 0.67$ & $1.35 \pm 0.32$ \\
Oyster-shell & 3 & $0.21 \pm 0.08$ & $0.04 \pm 0.01$ \\
Oyster-tissue & 3 & $9.27 \pm 0.60$ & $1.26 \pm 0.18$ \\
Polychaete worms & 6 & $6.84 \pm 1.12$ & $1.07 \pm 0.14$ \\
Shrimp-gravid & 2 & 8.95 & 2.44 \\
Shrimp-not gravid & 4 & $9.35 \pm 0.66$ & $2.59 \pm 0.37$ \\
\hline
\end{tabular}


Table 5. Assimilated nitrogen and phosphorus in average standing stock biomass (inclusive of shell) of major faunal groups at restored and control sites

\begin{tabular}{|c|c|c|c|c|}
\hline \multirow[t]{2}{*}{ Faunal group } & \multicolumn{2}{|c|}{ Nitrogen $\left(\mathrm{g} \mathrm{m}^{-2}, \pm \mathrm{SD}\right)$} & \multicolumn{2}{|c|}{ Phosphorus $\left(\mathrm{g} \mathrm{m}^{-2}, \pm \mathrm{SD}\right)$} \\
\hline & Control & Restored & Control & Restored \\
\hline Amphipods & $0.012 \pm 0.021$ & $0.160 \pm 0.167$ & $0.0051 \pm 0.0094$ & $0.0703 \pm 0.0733$ \\
\hline Anemones & $0.000 \pm 0.000$ & $0.455 \pm 0.807$ & $0.0000 \pm 0.0000$ & $0.0660 \pm 0.1171$ \\
\hline Barnacles & $0.000 \pm 0.000$ & $1.096 \pm 0.905$ & $0.0000 \pm 0.0000$ & $0.1550 \pm 0.1280$ \\
\hline Clams & $0.173 \pm 0.196$ & $1.344 \pm 1.333$ & $0.0146 \pm 0.0164$ & $0.1560 \pm 0.1552$ \\
\hline Crabs & $0.010 \pm 0.011$ & $3.515 \pm 3.185$ & $0.0034 \pm 0.0038$ & $1.2068 \pm 1.0935$ \\
\hline Fish & $0.030 \pm 0.036$ & $1.996 \pm 1.391$ & $0.0101 \pm 0.0122$ & $0.6779 \pm 0.4643$ \\
\hline Mussels & $0.002 \pm 0.002$ & $24.055 \pm 6.890$ & $0.0002 \pm 0.0003$ & $2.5825 \pm 0.7551$ \\
\hline Oysters & $0.000 \pm 0.000$ & $61.759 \pm 6.082$ & $0.0000 \pm 0.0000$ & $10.1241 \pm 0.9351$ \\
\hline Polychaete worms & $0.025 \pm 0.009$ & $0.827 \pm 0.260$ & $0.0039 \pm 0.0013$ & $0.1294 \pm 0.0406$ \\
\hline Shrimp & $0.003 \pm 0.005$ & $0.137 \pm 0.151$ & $0.0008 \pm 0.0013$ & $0.0365 \pm 0.0402$ \\
\hline Non-oyster macrofauna & $0.254 \pm 0.218$ & $33.587 \pm 8.856$ & $0.0381 \pm 0.0251$ & $5.0804 \pm 1.6152$ \\
\hline Oysters & $0.000 \pm 0.000$ & $61.759 \pm 6.082$ & $0.0000 \pm 0.0000$ & $10.1241 \pm 0.9351$ \\
\hline Total macrofauna & $0.254 \pm 0.218$ & $95.346 \pm 14.571$ & $0.0381 \pm 0.0251$ & $15.2054 \pm 2.4460$ \\
\hline
\end{tabular}

\section{DISCUSSION AND CONCLUSIONS}

\section{Biogeochemical fluxes}

Measurement approach

Measurement of the sediment-water exchange of substances generally requires sealing a part of the sediment community into a chamber, either in situ (e.g. benthic landers) or ex situ (e.g. cores), and measuring the change of the solute or gas concentration over time (e.g. Newell et al. 2002). Alternative approaches include measuring differences in inflow and outflow concentrations in flow-through incubations (e.g. Piehler \& Smyth 2011) or in situ measurements of oxygen fluxes using eddy correlation (e.g. Berg et al. 2003). In designing a system to measure net benthic fluxes, there are a number of key considerations: (1) inclusion of sufficient benthic habitat to provide good representation of benthic biota and physical structure; (2) minimizing disturbance of surface sediments where the most reactive material and abundant microbial communities are generally found; (3) maintenance of in situ temperatures which affect both microbial processes and the accuracy of the $\mathrm{N}_{2}$ : $\mathrm{Ar}$ approach to measuring denitrification (Kana et al. 1994); (4) avoiding excessive oxygen depletion or accumulation/depletion of other chemical species (e.g. ammonium, hydrogen sulfide) that can affect coupled nitrification/ denitrification, sediment-water exchange of SRP and benthic organism activity; and (5) incorporation of reasonable boundary-layer physical characteristics.

Our approach takes each of these issues into consideration. By excavating discrete segments of reef (area $=0.1 \mathrm{~m}^{-2}$ ) and placing them in trays that were re-imbedded in the substratum, a reasonable subset of the whole community was sampled. Disturbance associated with moving the whole community into trays was addressed by allowing $\sim 2$ wk of equilibration between manipulation and sampling, a duration that exceeds measured turnover rates for carbohydrates under aerobic conditions in Chesapeake Bay (Harvey et al. 1995) and thus allowed sufficient time for resupply of labile organic matter to compensate for any losses during excavation. Close proximity between the field sites and the laboratory limited negative effects due to alterations in temperature or oxygen saturation. In the laboratory, sampling trays were immediately placed in an aerated water bath with temperature and salinity matched to field conditions. An impeller in each chamber provided flow within the range of flow speeds observed in the field and sufficient to ensure thorough mixing of the water column without resuspension of sediments.

Multiday incubation of samples collected in October demonstrated that nitrogen fluxes change significantly as samples are held in the laboratory. $\mathrm{As} \mathrm{NH}_{4}{ }^{+}$ fluxes decrease, $\mathrm{NO}_{2+3}$ fluxes increase (Fig. 5), likely as a result of increased rates of nitrification. By the end of the incubation, there was also a slight increase in denitrification rates. Thus, the longer samples are held prior to incubation, the more likely it is that field nitrification and denitrification rates will be overestimated due to laboratory artifacts.

\section{Seasonal fluxes}

Fluxes of $\mathrm{O}_{2}, \mathrm{NH}_{4}{ }^{+}, \mathrm{NO}_{2+3}, \mathrm{~N}_{2}-\mathrm{N}$ and SRP were all at least an order of magnitude greater for the 
restored site than at the control site. Because we did not observe significant macrofaunal mortality during incubations, we are confident that these fluxes represent ongoing biological and biogeochemical processes and cannot be attributed to mortality of organisms within the chambers. The greatest differences in fluxes between the 2 sites were observed in $\mathrm{NH}_{4}{ }^{+}$ and $\mathrm{NO}_{2+3}$ for which rates were as much as 2 and 3 orders of magnitude higher, respectively, at the restored site than at the control site. Although high compared to the control site, ammonium fluxes fell within the range of ammonium fluxes previously measured for oyster reefs. Dame et al. (1989) report an average summer ammonium flux of $\sim 5 \mathrm{mmol} \mathrm{m}^{-2}$ $\mathrm{h}^{-1}$ from an oyster reef in South Carolina. In contrast, our fluxes of $\mathrm{N}_{2}-\mathrm{N}$ were much higher than those previously reported for oyster reef environments. Previous studies of denitrification associated with oyster reefs (Piehler \& Smyth 2011, Smyth et al. 2013), oyster biodeposition (Newell et al. 2002) and oyster aquaculture (Holyoke 2008) have relied on incubations of sediment cores and have not included living oysters within these cores. These studies report denitrification rates ranging from 0.0 to $0.33 \mathrm{mmol} \mathrm{N}_{2}-\mathrm{N}$ $\mathrm{m}^{-2} \mathrm{~h}^{-1}$, rates substantially lower than our observed rates of 0.25 to $1.59 \mathrm{mmol} \mathrm{m}^{-2} \mathrm{~h}^{-1}$.

Compared to fluxes of oxygen, nitrogen and phosphorus previously measured in soft sediment environments in Chesapeake Bay and its tributaries, the rates we measured for the restored site are far higher. A comprehensive review of oxygen and nutrient exchange measurements from Chesapeake Bay reported maximum values for oxygen demand, ammonium flux and nitrate flux of $9 \mathrm{mmol} \mathrm{O}_{2} \mathrm{~m}^{-2} \mathrm{~h}^{-1}$, $2.17 \mathrm{mmol} \mathrm{NH}_{4}-\mathrm{N} \mathrm{m}^{-2} \mathrm{~h}^{-1}$ and $0.28 \mathrm{mmol} \mathrm{NO}_{2+3}-\mathrm{N}$ $\mathrm{m}^{-2} \mathrm{~h}^{-1}$, respectively (Boynton \& Bailey 2008), compared to our maximum values of $39 \mathrm{mmol} \mathrm{O}_{2} \mathrm{~m}^{-2} \mathrm{~h}^{-1}$, $3.51 \mathrm{mmol} \mathrm{NH}_{4}-\mathrm{N} \mathrm{m}^{-2} \mathrm{~h}^{-1}$ and $1.83 \mathrm{mmol} \mathrm{NO}_{2+3}-\mathrm{N}$ $\mathrm{m}^{-2} \mathrm{~h}^{-1}$. Our maximum $\mathrm{N}_{2}-\mathrm{N}$ flux $\left(1.59 \mathrm{mmol} \mathrm{N}_{2}-\mathrm{N}\right.$ $\mathrm{m}^{-2} \mathrm{~h}^{-1}$ ) was also higher than any previously published values for soft sediments in Chesapeake Bay, where denitrification rates seldom exceed $0.18 \mathrm{mmol}$ $\mathrm{N}_{2}-\mathrm{N} \mathrm{m}^{-2} \mathrm{~h}^{-1}$ (Kemp et al. 2005, J. C. Cornwell \& M. S. Owens unpubl. data). Our August SRP flux (0.57 mmol $\mathrm{m}^{-2} \mathrm{~h}^{-1}$ ) was higher than any previously reported values for Chesapeake Bay sediments (Cowan \& Boynton 1996), including SRP releases observed with seasonal hypoxia $\left(\sim 0.15 \mathrm{mmol} \mathrm{m}^{-2} \mathrm{~h}^{-1}\right.$; Boynton 2000$)$ or elevated $\mathrm{pH}\left(\sim 0.11 \mathrm{mmol} \mathrm{m}^{-2} \mathrm{~h}^{-1}\right.$; Seitzinger 1991).

The denitrification and nitrification rates we observed for the restored site are among the highest values ever reported for an aquatic environment. Calculated nitrification rates for the restored site ranged from 0.72 to $3.43 \mathrm{mmol} \mathrm{N} \mathrm{m} \mathrm{m}^{-2} \mathrm{~h}^{-1}$. We are unaware of comparable rates in any ecosystem. A comprehensive review of coastal denitrification rates found 2 rates $\left(1.58\right.$ and $1.26 \mathrm{mmol} \mathrm{N}_{2}-\mathrm{N} \mathrm{m}^{-2} \mathrm{~h}^{-1}$ ) similar to our highest rate, but no others that were even half that value (Joye \& Anderson 2008). A crosssystem analysis of 107 datasets examined denitrification rates in aquatic systems during the warmest month and found only 3 studies, all riverine, with higher denitrification rates than those found at our restored site in August (Piña-Ochoa \& ÁlvarezCobelas 2006).

Because our nitrification and denitrification estimates are based on accumulation of $\mathrm{NO}_{2+3}$ and $\mathrm{N}_{2}-\mathrm{N}$ in the overlying water, our estimates represent 'net' fluxes and cannot be used to tease apart the contributions of all possible nitrogen pathways. Dissimilatory reduction of nitrate to ammonium (DNRA) can be an important sink for $\mathrm{NO}_{2+3}$ in some environments (An \& Gardner 2002). If DNRA was significant in our system, then our calculated nitrification rates underestimate actual nitrification rates. Although anammox has not been shown to be an important process in Chesapeake Bay sediments (Rich et al. 2008), the observed cooccurrence of oxidized $\mathrm{NO}_{2+3}$ and $\mathrm{NH}_{4}{ }^{+}$prevents us from eliminating the possibility that anammox could have occurred in our incubations. While we are not able to distinguish between the various pathways that lead to $\mathrm{N}_{2}-\mathrm{N}$ production, by measuring fluxes of $\mathrm{N}_{2}-\mathrm{N}$ in the water column, we did accurately measure the net effects of these pathways.

Although rates of nitrification and denitrification were consistently higher for the restored site than at the control site, efficiencies were not. Nitrification efficiency is a measure of the likelihood that ammonium molecules will be transformed into nitrite and nitrate via nitrification. Similarly, denitrification efficiency is a measure of the likelihood that nitrate and nitrite molecules will be transformed into nitrogen gas via denitrification. Both efficiencies are useful for comparisons between sites or systems. At the 2 sites we studied, patterns in nitrification and denitrification efficiencies varied, but the highest single values for each were found at the control site. However, it is important to consider these efficiencies in the context of total nitrogen fluxes which were far higher at the restored site. In Chesapeake Bay, the efficiency of coupled nitrification-denitrification is spatially and seasonally variable, with low efficiencies in sub-pycnocline low oxygen mainstem environments (Kemp et al. 2005). In fine-grained Choptank River sediments, the efficiency of denitrification can range from $<10 \%$ in the summer to $>50 \%$ in spring and fall 
(Owens 2009). In contrast to our results and other data from Chesapeake Bay, data from intertidal oyster reef sediments in North Carolina suggest denitrification efficiencies of approaching $100 \%$ (Piehler \& Smyth 2011, Smyth et al. 2013). In eutrophic coastal environments, inefficient coupled nitrification-denitrification is generally attributed to low rates of nitrification because of minimal oxygen penetration into sediments (Kemp et al. 1990). On restored oyster reefs, direct excretion of ammonium to the water column is also a likely contributing factor.

We are confident that the high denitrification rates we measured are representative of actual rates rather than an artifact of our measurement approach for several reasons. First, fluxes measured for the restored site were consistently high between replicate runs of the same sample, across samples within each sampling period and across seasons. Second, our overall composition of remineralization was $116 \mathrm{C}: 15 \mathrm{~N}: 1 \mathrm{P}$. This ratio is similar enough to the expected Redfield ratio for marine algae of 106C: $16 \mathrm{~N}: 1 \mathrm{P}$ to confirm that our fluxes accounted for the majority of nitrogen and phosphorus transformations. Third, by the nature of their structure and faunal composition, oyster reefs provide ample microhabitats conducive to the establishment of communities of nitrifying microbes. Nitrification requires contact between remineralized nitrogen and the aerobic nitrifying community. In soft sediments, oxygen penetration is limited and nitrifiers often inhabit only the top few millimeters of sediment. In contrast, oyster reefs have as much as $50 \mathrm{~m}^{2}$ of surface area per square meter of reef (Bahr 1974), providing ample habitat for nitrifiers on the exterior of live and dead oysters. Nitrification activity has also been found directly associated with the surfaces of living organisms, including polychaetes, amphipods and the surfaces of bivalve soft tissues (Welsh \& Castadelli 2004). Finally, denitrification rates on oyster reefs are expected to be highest for reefs in oxic waters below the euphotic zone where microbes need not compete with benthic algae for nitrogen compounds and where reduced oxygen levels do not inhibit coupled nitrification-denitrification. The restored site was located at a depth of $\sim 4 \mathrm{~m}$, where it received very little or no light. During our study, dissolved oxygen levels never dropped to anoxic or hypoxic levels in the vicinity of the restored site. These factors combined with an abundant supply of organic matter likely led to optimal conditions for both nitrification and denitrification.

The role that restored oyster reefs play in controlling levels of SRP in the water column is less straight- forward. Phosphorus fluxes in estuarine sediments vary widely and are highly dependent upon local factors including sediment characteristics, degree of eutrophication, $\mathrm{pH}$ levels and bioturbation (Howarth et al. 2011). The large SRP effluxes observed at the restored site are unusual in aerobic Chesapeake sediments (Boynton \& Kemp 1985) and suggest poor binding of $\mathrm{P}$ to sediments, direct excretion of SRP from the macrofaunal community to the water column, or both. Regardless of the mechanism, the highly efficient recycling of SRP to the water column indicates that biogeochemical processes at the restored site were not a significant sink for phosphorus and that the primary mechanism for potential phosphorus retention is assimilation into the tissues and shells of reef organisms.

\section{Macrofaunal abundance, biomass and nutrient content}

Macrofaunal abundances at the restored site were greater than those previously reported for restored oyster reefs in the Maryland portion of Chesapeake Bay (Rodney \& Paynter 2006), but within the range reported for natural reefs in Chesapeake Bay (e.g. Larsen 1985). Average standing stock biomass, assimilated nitrogen and assimilated phosphorus at the restored site were 2 to 3 orders of magnitude higher than at the control site. The percentage of nitrogen in oyster soft tissues in the present study were 8 to $32 \%$ higher than those previously reported (Newell 2004, Higgins et al. 2011, Carmichael et al. 2012), while the percentages of phosphorus were 52 to $58 \%$ higher (Newell 2004, Higgins et al. 2011). Percentages of nitrogen and phosphorus in oyster shell in the present study were 30 and $60 \%$ lower, respectively, than previously reported for wild oysters (Newell 2004), but fell within the range of values reported for oyster aquaculture (Higgins et al. 2011). We are unaware of any previous work that has attempted to estimate the nutrient assimilation (soft tissues and shell) by all macrofauna from a natural or restored oyster reef.

Variation in the percentage of nitrogen and phosphorus contained in oyster shell and tissue is relatively small compared to reported variation in the estimated total nutrient content per oyster. At the restored site, an average individual oyster contained $0.49 \pm 0.08 \mathrm{~g} \mathrm{~N}$ and $0.08 \pm 0.14 \mathrm{~g} \mathrm{P}$, with $0.24 \pm 0.05 \mathrm{~g}$ $\mathrm{N}$ and $0.03 \pm 0.01 \mathrm{~g} \mathrm{P}$ bound in tissue and $0.26 \pm$ $0.06 \mathrm{~g} \mathrm{~N}$ and $0.05 \pm 0.01 \mathrm{~g} \mathrm{P}$ bound in shell. Despite similar shell heights and lower tissue biomass, our 
oysters contained $25 \%$ more nitrogen and $62 \%$ more phosphorus than the largest size class of oysters examined by Higgins et al. (2011). Previous work on wild oysters provides estimates of total nitrogen and phosphorus content that are 5 and $97 \%$ greater, respectively, than the values in the present study despite smaller shell heights (Newell 2004). Estimates of nitrogen in the soft tissue of oysters with a shell height of $76.2 \mathrm{~mm}$ given by Carmichael et al. (2012) range from $16 \%$ lower than our values to $60 \%$ higher. Some of the variation in estimates of nutrient content per oyster in these studies stems from differences in the percent nitrogen and phosphorus estimates used in calculations, but most results from the differences in dry weights of oyster tissue and/or shell between studies. These differences highlight both the need for additional studies to document the range in \% $\mathrm{N}$ and \% $\mathrm{P}$ in oyster tissue and shell in relation to varying environmental conditions and the necessity of using site-specific relationships between oyster shell height, tissue dry weight and shell dry weight when calculating total nutrients per oyster.

Although we did not directly address the rates of nutrient assimilation or the fate of those nutrients once assimilated, our work demonstrates that significant amounts of nutrients are sequestered in the shells of Crassostrea virginica and the mussel Ischadium recurvum (Table 4 ). Including only the shells of oysters and mussels $>10 \mathrm{~mm}$, we estimate that $31.71 \pm$ $3.15 \mathrm{~g} \mathrm{~N} \mathrm{~m}^{-2}$ and $6.04 \pm 0.60 \mathrm{~g} \mathrm{P} \mathrm{m}^{-2}$ are contained in oyster shell and an additional $10.02 \pm 2.60 \mathrm{~g} \mathrm{~N} \mathrm{~m}^{-2}$ and $0.85 \pm 0.22 \mathrm{~g} \mathrm{P} \mathrm{m}^{-2}$ are contained in mussel shell. Combining these values, we estimate that $47 \%$ of $\mathrm{TN}_{\mathrm{ss}}$ and $48 \%$ of $\mathrm{TP}_{\mathrm{ss}}$ are assimilated into the shells of oysters and mussels. Because the shells of these organisms are expected to persist long after the organisms die, a significant portion of the standing stock of nutrients may be sequestered for years, decades, or even centuries if shells become buried below the taphonomically active zone (Waldbusser et al. 2011).

It is important to reiterate that we have not measured assimilation rates, but rather the standing stock of nitrogen and phosphorus assimilated into soft tissues and shells. While a substantial portion of the nutrients in shells are likely sequestered for considerable time, those in soft tissues will cycle through the system. Regardless of how long nutrients are retained within reef organisms and the structures they create, the $\delta^{15} \mathrm{~N}$ signatures of benthic macrofauna commonly increase with increasing anthropogenic nitrogen load, confirming that they assimilate anthropogenically derived nitrogen from their food sources (e.g. Martinetto et al. 2006, Carmichael et al. 2012). To the extent that this nitrogen flows through benthic and pelagic food webs without being remineralized, it will reduce the pool of nitrogen available for phytoplankton growth.

In addition to assimilating nutrients, oyster reef macrofauna play a significant role in altering biogeochemical cycling. Filter-feeding organisms were the most abundant functional group at the restored site and are the most likely explanation for the higher organic content of sediments at this site. Depositfeeding organisms including polychaetes and amphipods were also extremely abundant. Numerous studies have demonstrated that reworking of sediments by both infaunal filter feeders and deposit feeders alters organic matter turnover and nutrient recycling (reviewed by Welsh 2003) and can enhance denitrification rates (e.g. Nizzoli et al. 2007). Bacterial nitrification activity is also directly associated with the surfaces of many macrofaunal species including Neanthes succinea, the most abundant species of polychaete in our samples, and Corophium insidiosum, an amphipod species closely related to 2 of our most abundant species (Welsh \& Castadelli 2004).

\section{Water quality implications}

To investigate the potential for restored reefs to impact regional-scale water quality, we used annual denitrification rates from the present study in combination with estimates of restorable substratum area to calculate (1) the percentage of annual external nitrogen inputs to the Choptank River that could be removed by restoring oyster reefs to all suitable areas in this tributary and (2) the percentage of available bottom that would need to be restored to reduce nitrogen loads by an amount equivalent to recently mandated nitrogen reductions for the Choptank River. We chose to focus on nitrogen removal via denitrification because our data were not suited to estimating rates of assimilation, we did not collect data on nitrogen burial, and published estimates of oyster reef nitrogen burial rates (e.g. Newell et al. 2005) are based on data from soft sediment environments rather than oyster reefs. To estimate the amount of substratum in the Choptank River that is suitable for restoration, we used a combination of data from 3 separate surveys. According to the Maryland Bay Bottom Survey conducted between 1974 and 1983, the Choptank River had 6439 ha of oyster shell and hard bottom at that time (Smith et al. 2001). More recent side-scan sonar survey data that overlap many of these areas (2007 to 2012; NOAA Chesa- 
peake Bay Office and Maryland Geological Survey, unpubl. data) show that only $61 \%$ of the area originally identified as shell or hard bottom is currently suitable for oyster reef restoration, resulting in a total of 3914 ha. Ground truth data, collected by a stratified random patent tong survey in Harris Creek, a tributary of the Choptank River, indicate that only $44 \%$ of this area contains shell as the primary substratum (Paynter et al. 2012). Assuming these data are representative of the small-scale distribution of shell within areas identified as restorable bottom based on sonar surveys, we estimate that there are 1722 ha of restorable bottom in the Choptank River.

Subtracting the annual denitrification rate at our control site from that at our restored site yields an estimate of $556 \mathrm{~kg} \mathrm{~N} \mathrm{ha}^{-1} \mathrm{yr}^{-1}$ removed as a result of reef restoration. Published estimates of external nitrogen inputs to the Choptank River range from $1.5 \times 10^{6} \mathrm{~kg} \mathrm{~N} \mathrm{yr}^{-1}$ (USEPA 2010) to $2.5 \times 10^{6} \mathrm{~kg} \mathrm{~N}$ $\mathrm{yr}^{-1}$ (Lee et al. 2001). Using $2.0 \times 10^{6} \mathrm{~kg} \mathrm{~N} \mathrm{yr}^{-1}$ as the annual nitrogen load to the Choptank, we estimate that restoring oyster reefs to all suitable areas in the Choptank River would remove $\sim 48 \%$ of the total external nitrogen inputs annually. Along with other tributaries throughout the Chesapeake Bay, the reductions in nitrogen loads required to meet newly mandated restrictions have been published for all segments of the Choptank River. Adding all of the required reductions and entering zeros for any segments which already meet these requirements, we estimate that a total of $216219 \mathrm{~kg} \mathrm{~N}$ need to be removed from the system to meet current restrictions. According to our calculations, this amount of nitrogen could be removed by restoring oyster reefs to $23 \%$ of the available bottom.

There are important caveats to this conclusion. Scaling our values up to larger spatial scales assumes that (1) average oyster densities comparable to those at the restored site can be achieved on much larger scales; (2) denitrification rates scale linearly with oyster density, a requirement given that a large reef with the same average density will be spatially heterogeneous; and (3) differences in environmental conditions between restoration sites within the Choptank River do not significantly alter denitrification rates. It is important to recognize that oyster reef restoration is not a substitute for reduction in land-based inputs to the system, but rather a potential safety net to reduce additional downstream impacts. For example, all of the Choptank River segments that exceed allowable nitrogen loads are upstream of areas where salinity levels make oyster reef restoration feasible. Thus, nitrogen inputs will still have deleteri- ous impacts within the Choptank River system regardless of the level of oyster reef restoration. However, downstream oyster reefs have the potential to remove nutrients before they reach the main stem of Chesapeake Bay and contribute to environmental degradation there, an especially important function in late summer when denitrification rates on the reefs are high and those in deeper water often decline dramatically (Newell et al. 2005).

Although nitrogen loading to the Choptank River falls within the range of nitrogen loading rates considered by Carmichael et al. (2012), our estimates indicate that restored oyster reefs could have greater impacts on estuarine water quality than previously thought. The difference between our estimates and those calculated and reviewed by Carmichael et al. (2012) stem from several sources. First, our goal was to estimate the potential nitrogen removal by successfully restored mature oyster reefs to all currently viable areas within the Choptank River. The restored site in our study had $326 \pm 106 \mathrm{~g}$ DW oyster tissue $\mathrm{m}^{-2}$, a value that falls well within the range of oyster soft tissue biomass reported for natural reefs (e.g. Bahr 1976), but is far greater than that considered by Newell et al. (2005) when modeling the potential for oysters to remove nitrogen from the Choptank River. Newell et al. (2005) modeled nitrogen removal at biomass densities of 1 to $10 \mathrm{~g} \mathrm{DW} \mathrm{m}^{-2}$ and estimated that oysters could remove 0.6 to $6 \%$ of nitrogen inputs to the Choptank River via denitrification and burial. Because their model scales directly to oyster soft tissue biomass, applying their calculations to the biomass density in our study results in estimated nitrogen removal rates even greater than our own. In addition, $\sim 8.5 \%$ of the Choptank River is currently suitable for restoration, a percentage greater than that considered by Carmichael et al. (2012) in their calculations. Although our estimates are high relative to previous ones, they systematically underestimate the potential rates of nitrogen removal by restored oyster reefs because they do not include estimates of either longterm assimilation of nitrogen into shell or burial of nitrogen in biodeposits in sediments.

The concept of using bivalve populations to ameliorate anthropogenic impacts on water quality is not a new one. Early studies focused on the ability of bivalves to filter phytoplankton from the water column (e.g. Officer et al. 1982). Although the filtration of phytoplankton and other particulate organic material from the water column is the first step in pathways that lead to nutrient removal by bivalves, the fate of that phytoplankton varies widely between species and environmental settings. Many studies 
have focused on the potential impacts of aquacultured bivalve populations on water quality (e.g. Lindahl et al. 2005, Higgins et al. 2011). While it is evident that harvesting cultured bivalves would remove a significant amount of nutrients, few studies have measured comparable positive impacts resulting from enhanced denitrification in the underlying sediments, with some reporting the potential for negative impacts (e.g. Nizzoli et al. 2006, Holyoke 2008, Minjeaud et al. 2009, Higgins et al. 2013). Most studies that have estimated the water quality benefits of restored or natural bivalve populations have relied heavily on indirect estimates of their impacts. Newell et al. (2005) based denitrification rates in their model on laboratory studies of enhanced denitrification rates in soft sediments after addition of simulated biodeposits (Newell et al. 2002), and their burial estimates were based upon burial rates of nitrogen and phosphorus for soft sediments (Boynton et al. 1995). These values have been used by subsequent modeling efforts (e.g. Carmichael et al. 2012). To the best of our knowledge, Piehler \& Smyth (2011) and Smyth et al. (2013) report the only previously published values for denitrification based on measured rates for materials collected from a restored or natural Crassostrea virginica reef. The contrast in rates between those studies and our own highlights the need to clarify the influence of environmental factors (e.g. tidal regime, light regime, water depth, salinity and primary production) and reef structural characteristics (e.g. oyster abundance and biomass, macrofaunal assemblage and structural complexity) on denitrification and nutrient sequestration rates, and thereby refine our understanding of the role restored oyster reefs play in nutrient removal.

Acknowledgements. This project would not have been possible without extensive assistance from the staff of the University of Maryland Center for Environmental Science's Horn Point Laboratory, the Paynter Lab at the University of Maryland, College Park, and the Oyster Recovery Partnership. We especially thank J. Seabrease for machining and design assistance; S. Allen, V. Politano and H. Lane for assistance in the field; B. Gross and B. Gore for many hours spent assessing faunal samples; and C. Palinkas for analysis of sediment samples. We also thank D. Bruce and H. Lane for assistance with oyster reef survey data, and G. Shenk for assistance with estimates of nitrogen loading. We are grateful to 5 anonymous referees for insightful comments and suggestions that significantly improved this manuscript. Funding for this project was provided by GenOn Energy, Inc. (formerly Mirant Mid-Atlantic, LLC) in cooperation with the Oyster Recovery Partnership. This is Contribution Number 4743 from the University of Maryland Center for Environmental Science and Contribution Number 3269 from the Virginia Institute of Marine Science.

\section{LITERATURE CITED}

An SM, Gardner WS (2002) Dissimilatory nitrate reduction to ammonium (DNRA) as a nitrogen link, versus denitrification as a sink in a shallow estuary (Laguna Madre/Baffin Bay, Texas). Mar Ecol Prog Ser 237:41-50

Aspila KI, Agemian H, Chau ASY (1976) A semi-automated method for the determination of inorganic, organic and total phosphate in sediments. Analyst 101:187-197

Bahr LM (1974) Aspects of the structure and function of the intertidal oyster reef community in Georgia. $\mathrm{PhD}$ thesis, University of Georgia, Athens, GA

Bahr LM Jr (1976) Energetic aspects of the intertidal oyster reef communities at Sapelo Island, Georgia, USA. Ecology 57:121-131

Beck MW, Brumbaugh RD, Airoldi L, Carranza A and others (2011) Oyster reefs at risk and recommendations for conservation, restoration, and management. Bioscience 61: 107-116

> Berg P, Roy H, Janssen F, Meyer V, Jorgensen BB, Huettel M, de Beer D (2003) Oxygen uptake by aquatic sediments measured with a novel non-invasive eddy-correlation technique. Mar Ecol Prog Ser 261:75-83

Boynton WR (2000) Impact of nutrient inflows on Chesapeake Bay. In: Sharpley AN (ed) Agriculture and phosphorus management: the Chesapeake Bay. Lewis Publishers, Boca Raton, FL, p 23-40

Boynton WR, Bailey EM (2008) Sediment oxygen and nutrient exchange measurements from Chesapeake Bay, tributary rivers and Maryland coastal bays: development of a comprehensive database and analysis of factors controlling patterns and magnitude of sediment-water exchanges. UMCES Technical Report Series No. TS-54208, University of Maryland Center for Environmental Science, Solomons, MD

Boynton WR, Kemp WM (1985) Nutrient regeneration and oxygen consumption by sediments along an estuarine salinity gradient. Mar Ecol Prog Ser 23:45-55

Boynton WR, Garber JH, Summers R, Kemp WM (1995) Inputs, transformations, and transport of nitrogen and phosphorus in Chesapeake Bay and selected tributaries. Estuar Coasts 18:285-314

> Brumbaugh RD, Coen LD (2009) Contemporary approaches for small scale oyster reef restoration to address substrate versus recruitment limitation: a review and comments relevant for the Olympia oyster, Ostrea lurida Carpenter, 1864. J Shellfish Res 28:147-161

- Carmichael RH, Walton W, Clark H (2012) Bivalveenhanced nitrogen removal from coastal estuaries. Can J Fish Aquat Sci 69:1131-1149

Coakley JP, Syvitski JPM (1991) Sedigraph techniques. In: Syvitski JPM (ed) Principles, methods, and application of particle size analysis. Cambridge University Press, New York, NY, p 129-142

> Cowan JLW, Boynton WR (1996) Sediment-water oxygen and nutrient exchanges along the longitudinal axis of Chesapeake Bay: seasonal patterns, controlling factors and ecological significance. Estuaries 19:562-580

> Dame RF, Spurrier JD, Wolaver TG (1989) Carbon, nitrogen and phosphorus processing by an oyster reef. Mar Ecol Prog Ser 54:249-256

Grabowski JH, Brumbaugh RD, Conrad RF, Keeler AG and others (2012) Economic valuation of ecosystem services provided by oyster reefs. Bioscience 62:900-909

> Grizzle RE, Greene JK, Coen LD (2008) Seston removal by 
natural and constructed intertidal eastern oyster (Crassostrea virginica) reefs: a comparison with previous laboratory studies, and the value of in situ methods. Estuar Coasts 31:1208-1220

Harvey HR, Tuttle JH, Bell JT (1995) Kinetics of phytoplankton decay during simulated sedimentation: changes in biochemical composition and microbial activity under oxic and anoxic conditions. Geochim Cosmochim Acta 59:3367-3377

> Higgins CB, Stephenson K, Brown BL (2011) Nutrient bioassimilation capacity of aquacultured oysters: quantification of an ecosystem service. J Environ Qual 40:271-277

> Higgins CB, Tobias C, Piehler MF, Smyth AR, Dame RF, Stephenson K, Brown BL (2013) Effect of aquacultured oyster biodeposition on sediment $\mathrm{N}_{2}$ production in Chesapeake Bay. Mar Ecol Prog Ser 473:7-27

Holyoke RR (2008) Biodeposition and biogeochemical processes in shallow, mesohaline sediment of Chesapeake Bay. PhD thesis, University of Maryland, College Park, MD

> Howarth R, Chan F, Conley DJ, Garnier J, Doney SC, Marino R, Billen G (2011) Coupled biogeochemical cycles: eutrophication and hypoxia in temperate estuaries and coastal marine ecosystems. Front Ecol Environ 9:18-26

Joye SB, Anderson IC (2008) Nitrogen cycling in coastal sediments. In: Capone DG, Bronk DA, Mulholland MR, Carpenter EJ (eds) Nitrogen in the marine environment, 2nd edn. Academic Press, Amsterdam, p 868-915

- Kana TM, Darkangelo C, Hunt MD, Oldham JB, Bennett GE, Cornwell JC (1994) Membrane inlet mass spectrometer for rapid high-precision determination of $\mathrm{N}_{2}, \mathrm{O}_{2}$, and $\mathrm{Ar}$ in environmental water samples. Anal Chem 66: 4166-4170

Kemp WM, Sampou P, Caffrey J, Mayer M, Henriksen K, Boynton WR (1990) Ammonium recycling versus denitrification in Chesapeake Bay sediments. Limnol Oceanogr 35:1545-1563

$>$ Kemp WM, Boynton WR, Adolf JE, Boesch DF and others (2005) Eutrophication of Chesapeake Bay: historical trends and ecological interactions. Mar Ecol Prog Ser 303:1-29

Kennedy VS, Breitburg DL, Christman MC, Luckenbach MW and others (2011) Lessons learned from efforts to restore oyster populations in Maryland and Virginia, 1990 to 2007. J Shellfish Res 30:719-731

- Larsen PF (1985) The benthic macrofauna associated with the oyster reefs of the James River Estuary, Virginia, USA. Int Rev Gesamten Hydrobiol 70:797-814

Lee KY, Fisher TR, Rochelle-Newall EP (2001) Modeling the hydrochemistry of the Choptank River basin using GWLF and Arc/Info: 2. Model validation and application. Biogeochemistry 56:311-348

Lindahl O, Hart R, Hernroth B, Kollberg S and others (2005) Improving marine water quality by mussel farming: a profitable solution for Swedish society. Ambio 34: 131-138

Martinetto P, Teichberg M, Valiela I (2006) Coupling of estuarine benthic and pelagic food webs to land-derived nitrogen sources in Waquoit Bay, Massachusetts, USA. Mar Ecol Prog Ser 307:37-48

> Minjeaud L, Michotey VD, Garcia N, Bonin PC (2009) Seasonal variation in di-nitrogen fluxes and associated processes (denitrification, anammox and nitrogen fixation) in sediment subject to shellfish farming influences. Aquat Sci 71:425-435
Newell RIE (2004) Ecosystem influences of natural and cultivated populations of suspension-feeding bivalve molluscs: a review. J Shellfish Res 23:51-61

Newell RIE, Owens MS, Cornwell JC (2002) Influence of simulated bivalve biodeposition and microphytobenthos on sediment nitrogen dynamics. Limnol Oceanogr 47: $1367-1369$

Newell R, Fisher TR, Holyoke R, Cornwell J (2005) Influence of eastern oysters on nitrogen and phosphorus regeneration in Chesapeake Bay, USA. In: Dame R, Olenin S (eds) The comparative roles of suspension-feeders in ecosystems. Kluwer, Dordrecht, p 93-120

Nizzoli D, Welsh DT, Fano EA, Viaroli P (2006) Impact of clam and mussel farming on benthic metabolism and nitrogen cycling, with emphasis on nitrate reduction pathways. Mar Ecol Prog Ser 315:151-165

Nizzoli D, Bartoli M, Cooper M, Welsh D, Underwood G, Viaroli P (2007) Implications for oxygen, nutrient fluxes and denitrification rates during the early stage of sediment colonisation by the polychaete Nereis spp. in four estuaries. Estuar Coast Shelf Sci 75:125-134

Officer CB, Smayda TJ, Mann R (1982) Benthic filter feeding: a natural eutrophication control. Mar Ecol Prog Ser 9:203-210

Owens MS (2009) Nitrogen cycling and controls on denitrification in mesoahaline sediment of Chesapeake Bay. MS thesis, University of Maryland, College Park, MD

Parsons TR, Maita Y, Lalli CM (1984) A manual of chemical and biological methods for seawater analysis. Pergamon Press, New York, NY

Paynter KT, Michaelis A, Lane H (2012) Oyster population and habitat assessment Harris Creek and the Little Choptank River: 2011 progress report. Submitted to the NOAA Chesapeake Bay Office. University of Maryland, College Park, MD, p 1-81

Peterson CH, Grabowski JH, Powers SP (2003) Estimated enhancement of fish production resulting from restoring oyster reef habitat: quantitative valuation. Mar Ecol Prog Ser 264:249-264

Piehler MF, Smyth AR (2011) Habitat-specific distinctions in estuarine denitrification affect both ecosystem function and services. Ecosphere 2:art12

> Piña-Ochoa E, Álvarez-Cobelas M (2006) Denitrification in aquatic environments: a cross-system analysis. Biogeochemistry 81:111-130

Rich JJ, Dale OR, Song B, Ward BB (2008) Anaerobic ammonium oxidation (Anammox) in Chesapeake Bay sediments. Microb Ecol 55:311-320

Rodney W, Paynter K (2006) Comparisons of macrofaunal assemblages on restored and non-restored oyster reefs in mesohaline regions of Chesapeake Bay in Maryland. J Exp Mar Biol Ecol 335:39-51

Seitzinger SP (1991) The effect of $\mathrm{pH}$ on the release of phosphorus from Potomac estuary sediments: implications for blue-green algal blooms. Estuar Coast Shelf Sci 33: 409-418

Smith GF, Greenhawk KN, Bruce DG, Roach EB, Jordan SJ (2001) A digital presentation of the Maryland oyster habitat and associated bottom types in the Chesapeake Bay (1974-1983). J Shellfish Res 20:197-206

Smyth AR, Thompson SP, Siporin KN, Gardner WS, McCarthy MJ (2013) Assessing nitrogen dynamics throughout the estuarine landscape. Estuar Coasts 36:44-55

Stainton MP (1973) A syringe gas-stripping procedure for gas-chromatographic determination of dissolved inor- 
ganic and organic carbon in fresh water and carbonates in sediments. J Fish Res Board Can 30:1441-1445

Stunz GW, Minello TJ, Rozas LP (2010) Relative value of oyster reef as habitat for estuarine nekton in Galveston Bay, Texas. Mar Ecol Prog Ser 406:147-159

USEPA (US Environmental Protection Agency) (2010) Chesapeake Bay total maximum daily load for nitrogen, phosphorus and sediment. www.epa.gov/reg3wapd/tmdl/ ChesapeakeBay/tmdlexec.html (accessed 5 February 2013)

Waldbusser GG, Steenson RA, Green MA (2011) Oyster shell dissolution rates in estuarine waters: effects of $\mathrm{pH}$

Editorial responsibility: Matthias Seaman,

Oldendorf/Luhe, Germany and shell legacy. J Shellfish Res 30:659-669

Welsh DT (2003) It's a dirty job but someone has to do it: the role of marine benthic macrofauna in organic matter turnover and nutrient recycling to the water column. Chem Ecol 19:321-342

Welsh DT, Castadelli G (2004) Bacterial nitrification activity directly associated with isolated benthic marine animals. Mar Biol 144:1029-1037

Wilberg MJ, Livings ME, Barkman JS, Morris BT, Robinson J (2011) Overfishing, disease, habitat loss, and potential extirpation of oysters in upper Chesapeake Bay. Mar Ecol Prog Ser 436:131-144

Submitted: July 4, 2012; Accepted: March 11, 2013

Proofs received from author(s): April 8, 2013 